\title{
Measuring the Haqā'iq al-Tafsir: From its Contentious Nature to the Formation of Sunnite Sufism
}

\author{
Mohammad Anwar Syarifuddin ${ }^{1}$
}

\begin{abstract}
This article discusses the Haqā'iq al-Tafsī by al-Sulami against the extant accusation of being Shi'ite. It is a certainly Sunnite commentary accumulated from their-own traditional sources as well as representing Sunnite theological principles. Despite its contentious title as well as the use of weak hadiths, the nature of Sulami's tafsir was relatively free from either Shi'ite elements or mystico-philosophical notions contradictory to the spirit of Sunnite orthodoxy. Al-Sulami's tafsiris is to be classified ma'thür, but it conceives spiritual significances (haqa'iq) that might have been set beyond the common objectives of Qur'anic tafsir in general. It is not a general tafsir for laymen, but an esoteric interpretation of the Qur'anic verses for the elites of sufi readers.
\end{abstract}

\begin{abstract}
Abstrak
Artikel ini mendiskusikan Haqā'iq al-Tafsīir karya al-Sulamī untuk menentang tuduhan terhadapnya sebagai seorang pengikut Shīa. Penulis artikel ini membuktikan bahwa karya ini merupakan penafsiran Sunnī yang didasarkan dari sumber tradisi Sunni dan juga merepresentasikan prinsip teologis Sunni. Walaupun judulnya kontroversial dan merujuk kepada hadith-hadith da' $\overline{\text { if, }}$ tafsir Sulami bebas dari elemen Shī'a ataupun doktrin mistikofilosofis yang bertentangan dengan spirit ortodoksi Sunni. Tafsir al-Sulami termasuk tafsir bi al-ma'thür namun ia mengandung pemaknaan spiritual (haqā'iq) yang dapat dianggap keluar dari tujuan umum penafsiran al-Qur'ān secara umum. Tafsir ini bukan termasuk tafsir untuk masyarakat awam, akan tetapi penafsiran esoteris terhadap al-Qur'ān untuk kalangan elit dari para sufi.
\end{abstract}

Keywords: Islamic spirituality, esoteric interpretation, Sufi Qur'ān commentary, Sunnite Sufism, scripturally based Sufism. 


\section{Introduction}

The Haqä'iq al-Tafsir may have been one of the greatest achievements in the history of the development of mystical commentary on the Qur'ān. Not only because it comprises two huge volumes of tafsir, which was much more extensive than its predecessor, the Tafsir al-Qur'ān al-Azim by Sahl al-Tustari (d. 289/896). ${ }^{2}$ Tustari's Tafsir had been diffused at the end of $3^{\text {rd }} / 9^{\text {th }}$ century in Basra, whereas the Haqā'iq al-Tafsir were published two centuries later at the turn to $5^{\text {th }} / 11^{\text {th }}$ century, but it specifically had incited wide-spread reactions among the Muslim scholarship. In a broader scope than al-Tustari's Tafsiri, the Haqā'iq al-Tafsir includes almost all exegetical materials derived from Sahl alTustari, along with all other sayings and accounts al-Sulami could gather from his Sufi precursors called by the epithet "the people of profound reality" (ahl alHaqā'iq). ${ }^{3}$

Looking from the general nature of a traditional work of Qur'anic exegesis, al-Sulami's method of arranging those mystical traditions into a structure of interpretation of the Qur'ānic verses in his Haqa'iq al-Tafsir can be compared to Ibn Jarir al-Tabarì's method in his Jami' al-Bayān 'an Ta'wī ày alQur'ān. Both tafsirs employ the traditional style of interpretation based on transmitted exegetical materials (al-tafsir bi al-ma'th $\bar{u}$ ). Both al-Tabari and alSulami were also traditionists whose intellectual linkage meets indirectly in the revered figure of the Shāfi'ite jurist Abū Bakr Muhammad b. 'Alī b. Ismā' $\bar{i} l$ alQaffāl al-Shāshī al-Marwazī (d. 365/976). ${ }^{4}$ al-T a abari was al-Qaffāl's teacher, whereas al-Sulami was al- Qaffā's disciple. The only slight difference between the two works is that unlike al-Tabari who provided full lists of transmission, for the most cases of interpretations al-Sulami simplified the lists of transmission by reducing them into certain principal authorities among the most prominent Sufi figures. In all, there is a unique nature of al-Sulami's Haqā'iq

${ }^{2}$ Sahl b. 'Abd Allāh b. Yūnus b. 'Isā b. 'Abd Allāh b. Rāfi' al-Tustarī was born in Tustar in 200/816. He became a Sufi under the guidance of his maternal uncle Muhạmmad b. Sawwār and Dhū al-Nūn al-Mișri (d. 246/861) (Ibn Khallikān, Wafayāt alA ‘yān wa Anbā' Abnā' al-Zamān, Edited by Iḥsān 'Abbās (Beirut: Dār Șādir, 1868), ii, $150 ;$ I, 389).

${ }^{3}$ Haqà'iq al-Tafsìir: Tafsìir al-Qur'ān al-'Azìz, ed. Sayyid 'Imrān (Beirut: Dār alKutub al-'Ilmiyya, 2001), I, 20.

${ }^{4}$ Al-Qaffal belonged to multi academic talent, as he renowned to be a jurist, traditionist, as well as linguist in the Shăfi $\bar{i}$ i school of Islamic law. He took traditions from Ibn Jarir al-Tabari, while among the Nishapuri traditionists who received his traditions afterwards were Abū 'Abd al-Rahmān al-Sulami (d. 412/1021) and al-Ḥakim al-Naysabūri. See his biography in Ibn Khallikān, Wafayāt al-A 'yān, IV, 200-1, also alSubkì, Tabaqāt al-Shāfí 'iyya al-Kubrāa, Ed. Mạ̣mūd Muḥammad al-Ṭanāḥ̄i and 'Abd alFattāḥ Muhammad al-Ḥuluw (Cairo: Isā al-Bābỉ al-Ḥalabì, 1964), III, 200-227. 
al-Tafsir, in which he confined his collection to provide only symbolic interpretations of the Qur'ān, compared to the vast varieties of exegetical genre within al-Tabari's tafsir. ${ }^{5}$

On the basis of such a unique character, there is an extant presumption that the Haqā'iq al-Tafsir had been accused to have shared the nature of a Bătini $\bar{i}$ ta'wìl, which consequently gives the Haqa'iq its Shi'ite flavor. Such opinion is found in al-Dhahabi despite his doubt on the validity of such claim. ${ }^{6}$ Such harsh criticism also appears in al-Suyuțî, when he asserted that alSulami's tafsir was accused of being "untrustworthy". ${ }^{7}$ In these two demeaning responses to the Haqa'iq al-Tafsir, the accusation of al-Sulami's being a Qarmați might have been based on his quotes from al-Hallāj. ${ }^{8}$ Besides, there are also several objections posed by other scholars of non-Shafi'te madhhabs, who put their comments against the sincere intention of al-Sulami within the intensive project of enrooting Sufism to the Qur'anic basis along with the formation of Sunnite orthodoxy. This piece will measure the Haqā'iq al-Tafsir to be a book of tafsir representing not a Shi'ite style of allegorical ta'wìl, but a Sunnite traditional commentary accumulated from their-own traditional sources as well as representing a Sunnite traditional perspective.

\section{Sulami's Being A Sufi Traditionist}

Abū 'Abd al-Raḥmān Muhammad b. al-Ḥusayn b. Muhammad b. Mūsā b.

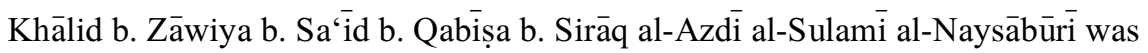
born on $10^{\text {th }}$ Jumāda al-Ākhira $325 / 927$ in Nishapur. ${ }^{9}$ He belonged to the clan of

${ }^{5}$ Al-Khațīb al-Baghdādī, Tārīkh Baghdād aw Madīnat al-Salām (Beyrut: Dār alKitāb al-'Arabī, 1970), II, 248.

${ }^{6}$ Al-Dhahabì's said, "wa lahu kitāb sammāhu "Haqā'iq al-Tafsìr” laytahu lam

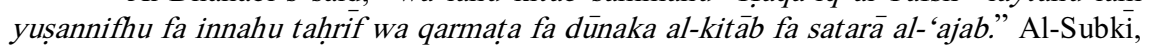
Tabaqāt al-Shāfí 'iyya al-Kubrā, IV, 147.

${ }^{7}$ He wrote, "wa innamā awradtuhu fì hàdha al-qismi lianna tafsìrahu ghayru mahmūud." Al-Suyūtịi, Tabaqāt al-Mufassirīn, ed. 'Alì Muhammad 'Umar (Cairo: Maktaba Wahba, 1977), I, 98.

${ }^{8}$ See L. Gardet, "al-Hallādj" in The Encyclopaedia of Islam, New Edition (Leiden: E.J. Brill, 1971), ed. B. Lewis [et.al.], III, 99b. Extracts of Hallāj's accounts in the Haqa'iq al-Tafsir is specifically collected by Massignon, see Massignon, Essai sur les origines du lexique technique de la mystique musulmane (Paris: J. Vrin, 1954), 359 412.

${ }^{9}$ This date is according to Abu Sa'īd Muhammad b 'Ali al-Khashshāb as quoted in al-Dhahabī, Siyar A 'Tām al-Nubalā', Ed. Shu'ayb al-Arna'ūt (Beirut: Mu'assasa alRisāla, $9^{\text {th }}$ edition, 1993), XVII, 247; Dhahabi also quoted 'Abd al-Ghafir al-Farisi in his Siyaq Naysabür mentioned that al-Sulami was born in 330 (al-Dhahabī, Siyar A 'läm alNubalā, XVII, 250). 
al-Azd ${ }^{10}$ from the side of his father and to that of Sulaym from the side of his mother. His maternal grandfather Abū 'Amr Ismāi'īl b. Nujayd al-Sulamì (d. 365/976), a proponent of the Malāmatiyya movement, played a very dominant role in directing Sulami's basic and advance studies in traditional Islamic sciences ("ilm al-zāhir). ${ }^{11}$ According to al-Subki, ${ }^{12}$ al-Sulami was linked through his maternal grandfather to a number of renowned authorities among Nishapuri traditionists. $^{13}$ Besides, Sulami made his own extensive travels outside Nishapur to visit neighboring regions such as Marw, Iraq, and the Hijāz, where he collected hadith from other respected figures of the $4^{\text {th }} / 10^{\text {th }}$ century traditionists. $^{14}$

${ }^{10}$ The ancestral root of the clan of al-Azd is traced back to Azd Shanū'a b. alGhawth b. Nabat b. Mālik b. Zayd b. Kahlān b. Saba' (al-Suyūți, Lubb al-Albāb fì Tahrì al-Ansāb, eds. Muḥammad Aḥmad 'Abd al-'Azīz, and Ashraf Aḥmad 'Abd al-'Aziziz (Beyrut: Dār al-Kutub al-'Ilmiyya, 1991), I, 50).

${ }^{11} \mathrm{Al}-\mathrm{Sulami}$ in his introduction to the Haqa'iq al-Tafsir identified the "outward sciences" as the Islamic traditional sciences such as the varieties of Qur'anic recitation (qirā'āt), some sorts of Qur'ānic interpretation (tafäsir), and other dimensions of Qur'ānic sciences such as its unsolved questions (mushkilāt), legal judgments (ahkām), desinential inflection ( ${ }^{\prime}$ räb), linguistics (lugha), general concepts and details (al-mujmal wa al-mufașsal), as well as abrogative and abrogated verses (al-nāsikh wa al-mansūkh). Al-Sulami, Haqà'iq al-Tafsiri, I, 19.

${ }^{12}$ Al-Subkì, Tabaqāt al-Shāfi 'iyya al-Kubrā, IV, 144.

${ }^{13}$ Among the renowned transmitters of hadith introduced by Ibn Nujayd himself to his grandson were Abū al-'Abbās al-Așamm (d. 346), Aḥmad b. 'Alī b. Hasnūyah alMuqri', Ahmad b. Muḥammad b. 'Abdūs (d. 346), and Muhammad b. Ahmad b. Sa'ìd alRāzi. Safadi said that Muhammad b. Ya'qūb b. Yūsuf b. Ma'qal b. Sinān b. Abu alAbbās al-Umawi al-Naysabūîi al-Așamm was a reliable transmitter of hadith. He had spent his time for seventy six years being a traditionist as he died in 346/957 (al-Safadi, Das Biographische Lexikon des Salāhaddìn al-Khalìl ibn Aibak al-Safadī Kitāb al-Wāfī bi al-Wafayāt, Ed by H. Ritter, Iḥsān 'Abbās, S. Dedering, M.Y. Najm, A. Amara and J. Sublet, Widad al-Qāḍi, Aiman Fu'ād Saiyid, B. Jonkisch and M. al-Hujairi (Wiesbaden: Franz Steiner Verlag, 1962-1988; Beirut: in kommission bei Klaus Schwarz Verlag Berlin, 2004), 1931, II, 171); whereas al-Dhahabi clarified that the other two transmitters were also reliable as he said that Ahmad b. 'Ali b. Hasnūya al-Muqrì' alNaysabūri was considered reliable by his disciple al-Ḥākim al-Naysaburi (al-Dhahabi, Mizān al-I'tidāl fī Naqd al-Rijăl, ed. 'Alì Muhammad al-Bajawì, Cairo: Dār Iḥyā' alKutub al-"Arabiyya, 1963, I, 121), as well as Abū al-Ḥasan Ahmad b. Muhammad b. Abdūs b. Salima al-Naysabūri al-Tarā'ifî was considered truthful (sadūq) by al-Hakim. See al-Dhahabi, Siyar A 'lām al-Nubalā', XV, 519-20. However, there is no information about Muhammad al-Razi, except that he is an associate of Ibn Wārah (al-Dhahabìi, Siyar A 'läm al-Nubalā, XVII, 163), despite a number of accounts quoted from him by alSulami in his Tabaqàt al-Süfiyya.

${ }^{14}$ Among the teachers of hadith whom he met within his travel were Abū Zahīr 'Abd Allāh b. Fāris al-'Umrī al-Balkhī, Muhammad b. al-Muhammil al-Māsarakhsīi, al-

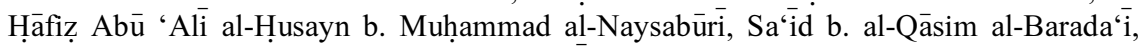
Aḥmad b. Muḥammad b. Rumayh al-Nasawi, Abū 'Abd Allāh al-Ṣaffār, Muḥammad b.

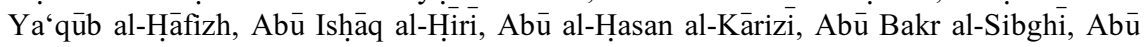




\section{Being Traditionist within a Malämati Background}

Al-Sulami's bright career as a traditionist was echoed by one of his contemporaries al-Khațib al-Baghdadi, who met al-Sulami listening to his hadith during the latter's stay at Baghdad. Al-Khațib asserted that al-Sulami had been specifically interested in collecting mystical traditions (akhbār süfiyya). Several works comprising a codex of mystical traditions (sunan süfiyya), a work on Qur'ānic exegesis, as well as hagiographic treatises were attributed to his name. ${ }^{15}$ In his Tabaqăt al-Shäfi 'iyya al-Kubra, al-Subkī wrote that al-Sulami had dedicated to the field of hadith for forty years. ${ }^{16}$ Such a long period of traveling and teaching prophetic traditions had made al-Sulami an expert of hadīth. Murād b. Yūsuf al-Dūsì in his Shams al-āfāq fī dhikr al- ba'ḍ

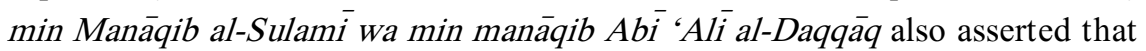
al-Sulami had also involved in teaching activities of the "outward sciences" (al'ulüm al-zāhira) as well as issuing fatwas. ${ }^{17}$

There is no definite work showing al-Sulami's contribution to the field of fatwas, but scrutinizing certain treatises and Sufi manuals composed by alSulami during his lifetime, such as Kitāb al-Samā', Kitāb al-Arba'īn fí alTasawwuf, the Risāla al-Malämatiyya, and the Kitäb al-Futuwwa will lead us to see that those works were composed in relation to the extent requests by his audiences. These types of works were intended to provide answers on specific problems posed to him, which may have resembled the question-answer type of the fatwa literature. In such particular treatises al-Sulami explained specific issues based on his skillful analyses employing transmitted materials of the prophetic traditions. After all, we can say that by being a traditionist, al-Sulami was able to compose almost a hundred works comprising a wide range of Islamic traditional sciences. ${ }^{18}$

\section{His Spiritual Masters: al-Ṣu'lūkī and al-Nașrābādhī}

Al-Sulami's attraction to Sufism came through the hands of Ibn Nujayd, who sent him to his colleague Abū Sahl Muhammad b. Sulayman al-Ṣu'lūkì (d.

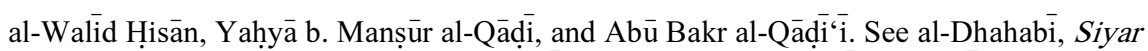
A 'Tàm al-Nubalā', XVII, 249-50; al-Ṣuyūî̀, Ṭabaqāt al-Mufassirìn, ed. 'Alì Muhammad 'Umar (Cairo: Maktaba Wahba, 1977), I, 98.

${ }_{15}$ Al-Khațib, Tärīkh Baghdād aw Madinat al-Salām, II, 248.

${ }^{16}$ Al-Subkì, Tabaqāt al-Shāfi 'iyya al-Kubrā, IV, 144.

17 Al-Sulami, Adāb al-Suhba wa Husn al-'Ishra, edited with an introduction by M.J. Kister (Jerusalem: The Israel Oriental Studies, 1954), 4.

18 The number of his works reach even more than a hundred according to an account of 'Abd al-Ghāfir al-Fārisi as cited by al-Subki. See al-Subkī, Tabaqāt alShāfi 'iyya al-Kubrāà, IV, 144. 
$369 / 980)^{19}$ in order to receive the latter's spiritual training. Al-Ṣu'lūki was a moderate Sufi associated to the Junaydian line of the Baghdadi mystical tradition. He also belonged to a family with profound knowledge of the Shäfi'ite School of Islamic law. With this strong scholarly background in both fiqh and ascetic experiences, al-Ṣu'lūki was the most suitable teacher for alSulami considering his Malāmatiyya backround trained under the auspices of Ibn al-Nujayd. Al-Șu'lūkì's fullname is Abū Sahl Muhammad b. Sulayman b. Muhammad b. Hārūn b. Bishr al-Hanafī al-'Ijlì. He was born in the neighboring region of Isfahān in around 296/908. His nisba to al-Hanafī refers to the Banū Hanifa al-'Ijli, not the Hanafite legal school. He passed away in Dhū al-Qa'da $369 / 980 .^{20}$ The nisba al-Ṣu'lūkì, meaning a 'desert wanderer' attributed to him as he embraced Sufism, was probably opposed to his legist background of a rich family. On a cold winter day in Isfahan, he gave his cloak to a poor man. He clothed himself in a woman's robe [probably belongs to his wife as he posessed no spare cloak] in order to attend his class in Islamic law. At last, his return to Nishapur for the funeral of his uncle Abū Tayyib Aḥmad al-Ṣu'lūki in 337/949 ${ }^{21}$ resulted in a permanent stay in the city as he, then, decided to stop wandering and finally settled down in Nishapur. ${ }^{22}$

As a Sufi under the auspices of Șu'lūki, al-Sulami underwent harsh spiritual trainings. The story of his initiatory ritual in Sufism up to receiving the degree of perfection, including the permission to raise disciples, is illustrated by M.J. Kister in his introductory section of the edition of alSulami's Adāb al-Ṣuhba. Quoting an unpublished treatise Shams al-Afãq fi Dhikr al-ba'ḍi min manāqib al-Sulamī wa min manāqib Abì 'Alì al-Daqqāq by Murād b. Yūsuf al-Ḥanafī al-Dūsì, Kister wrote:

"Al-Sulami took the spiritual path (tariqa) and Gnostic knowledge (ma'rifa) of the peaks of Sufism from Shaykh Abū Sahl al-Ṣu'lūki, who taught him divine recollection (dhikr) and took the pledge of allegiance to stand for being his child. He [i.e. al-Șu'lūki] then instructed him to join in his seclusion (khalwat), and to recite [certain] divine names which were suit to. Then, he left him alone in a forty night seclusion (al-khalwat al-arba'iniyya) until God opened his heart. Then, by his blessed hands Șu'lūki clothed him with the garment of the sincere poor. Sulami continued to undergo his seclusion until God lets the master [i.e. al-Ṣu'lūki] know as he

\footnotetext{
${ }^{19}$ See his biography in al-Dhahabî, Siyar A 'lām al-Nubalā', XVI, 235-240.

${ }^{20}$ Al-Dhahabi, Siyar A 'lām al-Nubalā', XVI, 239.

${ }^{21}$ For his biography, see al-Dhahabì, Siyar A 'lām al-Nubalā', XV, 391.

${ }^{22}$ See Bulliet, The Patricians of Nishapur: A Study in Medieval Islamic Social History (Cambridge, MA: Harvard University Press, 1972), 115-116.
} 
envisions by his inner sight and the strength of intuitive knowledge (firāsa) that this al-Sulami was of the people whom God had opened his profound reality, and He had [also] made him reach the degree of perfection among the Sufis. Consequently, the master granted him permission to raise disciples. Then, for the continuing period al-Sulami began to raise disciples, as many people came to company and grow up with him, take benefits from him, and graduate under his auspices." 23

Kister concluded from al-Dūsi's eclectic accounts on al-Sulami's initiation that al-Sulami not only received the Sufi cloak from Abu Sahl alSu'lūki, but he also received an investiture of the white garment of Junayd by the hands of Abū al-Qāsim al-Nașrābādhī (d. 367/978), one of Șu'lūkī's colleagues. $^{24}$

Abū al-Qāsim Ibrāhīm b. Muḥammad b. Mahmūya al-Naṣrābādhì was a native Nishapurì. Al-Ḥākim al-Naysabūrì testified that al-Nașrābādhī was the tongue of the people of profound reality at his time, as he was also renowned for his sound spiritual states. ${ }^{25}$ He began his intellectual career as a traditionist. He learned hadith from several traditionists in Nishapur. ${ }^{26}$ When he traveled for more than twenty years, he became a preacher $\left(w^{-}{ }^{-i} i\right)^{27}$ as well as listening to

${ }^{23} \mathrm{He}$ wrote, "akhadha (ay al-Sulamī) al-tarīqa wa ma'rifa atwār al-sulūk 'an alshaykh al-imām al- 'ārif billāh ta'āla....al-ustādh Abì Sahl al-Ṣu'lūkì wa laqinahu al-dhikr wa akhadha 'alayhi al-mubaya'a bi annahu waladuhu hissan wa ma'nan. Thumma amarahu bi idkhālihi li al-khalwa wa amarahu bi iqrā'i ismin bimā yunāsibuhu min alasmā' thumma akhlāhu 'indahu fi al-khalwa al-arba 'iniyya ilā an fataha Allāhu 'alayhi. Thumma albasahu khirqat al-fuqarā' al-șàdiqīn min yadihi al-mubāraka. Wa lam yazal bitilka al-khalwa hattā atla'a Allāhu al-shaykh wa ra'à bi ayn al-bașira wa quwwati alfirāsa anna hädhà al-Sulamí mimman fataḥa Allāh ta'āla 'alayhi haqiquatahu wa hașala lahu al-kamāl min bayni al-rijal falidhā a țāhu al-ijaza bi tarbiyat al-murìin. Thumma akhadha ba'da dhālika bitarbiyat murìihi $\bar{i}$ wa șahabahū khuluqun kathìr wa intammū ilayhi wa intafa' 'ù bi suhbatihi wa takharrajū min tahti tarbiyyatihi (Al-Dūsì, Shams alAfăq, fol. 62 as quoted in M.J. Kister's editorial notes for Sulami, Ádāb al-Suḥba wa Husn al-'Ishra, 4.

${ }^{24}$ See Böwering, "The Qur'ān Commentary of al-Sulami,", in W.B. Hallaq and D.P. Little (Eds.), Islamic Studies Presented to Charles Adams (Leiden: E.J. Brill, 1991), 44.

${ }^{25}$ Al-Dhahabī, Siyar A 'lām al-Nubalā', XVII, 265.

${ }^{26}$ In Nishapur he heard hadith from Abū Bakr b. Khuzayma, Abū al-'Abbās alSarrāj, Aḥmad b. Muḥammad b. Al-Azhar. Ibn 'Asākir, Tārikh Madīna Dimashq wa

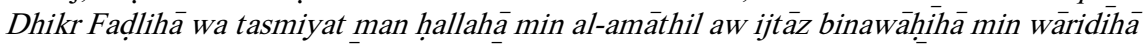
wa ahlihä, Ed. Muhị al-Dīn Abū Sa'ìd 'Umar b. Gharāma al-'Amrāwì (Beirut: Dār elFikr, 1995), VII, 103.

${ }^{27}$ Al-Dhahabìi, Siyar A 'lām al-Nubalā', XVI, 265; Ibn 'Asākir, Tārìkh Madīna Dimashq, VII, 103. 
hadith from several traditionists in Baghdad. ${ }^{28}$ During his stay in Baghdad he was attracted to engage in Sufism under the guidance of Abu Bakr al-Shibli (d. $334 / 946) .{ }^{29}$ In addition, he continued to study hadith when he, then, traveled to Syria and Egypt. ${ }^{30}$ He returned to Nishapur in around $340 / 952 .{ }^{31}$ He spent his last days in Makka from 365/976 ${ }^{32}$ up to his demise in Dhū al-Hijja 367/978. ${ }^{33}$

It was through al-Nașrābādhi's teacher that al-Sulami was strongly linked to the Baghdadi Sufi circle, whose mystical genealogy reaches to the authority of al-Junayd. The Baghdadi mystical principles that seemed to have been inherited from Junayd are clearly shown in al-Nasrābādhi' primary principles of scripturally based Sufism as he said, "The main principles (ușūt) of taṣawwuf are persevering the Holy Scripture and prophetic traditions, leaving desires and innovations, augmenting the masters' honor, looking upon the people's impediments, habituating to perform continuous dhikr, as well as to avoid taking exemptions (rukhas ) and excessive interpretations." ${ }^{34}$ Besides, what is preserved by al-Nasrābādhi from the main characteristic of Junaydian nature of mystical teaching is reported in al-Sulami's Tabaqāt al-Süfiyya, in which al-Nasrābādhi concluded, "Nobody will go astray on this path except by a wrong start, because the mistaken start affects to the [wrong] end." ${ }^{35}$ As both al-Ṣu'lūki and al-Nașrābādhi took mystical counsels from al-Shibli $\bar{i}{ }^{36}$ it was

${ }^{28}$ Among them were 'Abd Allāh b. Muhammad b. al-Ḥasan al-Sharqi, Ahmad b. Muhammad b. Yahyāa b. Bilāl al-Naysabūrì, Muḥammad b. 'Ab̉ Allāh b. 'Abd al-Salām Makhūul al-Bayrūtì. Al-Khațīb, Tărikh Baghdād aw Madīnat al-Salām, VI, 169.

${ }^{29}$ Besides al-Shibli, according to Ibn 'Asākir, al-Nașrāādhi was also took the spiritual guidance of Abū 'Alì al-Ruḍbāìi. See Ibn 'Asākir, Tàrìkh Madīna Dimashq, vol. VII, 104.

${ }^{30}$ Ibn 'Asākir, Tārikh Madina Dimashq, VII, 103. He heard hadith from Ahmad b. 'Amīir in Damascus, Makhūl al-Bayrūtì in Beirut; Aḥmad b. 'Abd al-Wārith and Abū Ja'far al-Ṭahāwi in Egypt.

${ }^{31}$ Ibn 'Asākir, Tárìkh Madina Dimashq, VII, 104.

32 This date is according to al-Dhahabì, Siyar A 'lām al-Nubalā', XVI, 265. However, some other sources mentioned that it was the year 366/977. See al-Khatib, Tärīkh Baghdād aw Madīnat al-Salām, VI, 169; Ibn 'Asākir, Tārikh Madīna Dimashq, VII, 109.

${ }^{33}$ Al-Dhahabì, Siyar A 'lām al-Nubalā', XVI, 265.

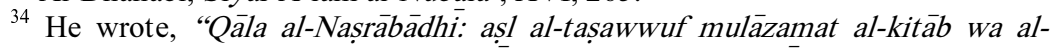
sunna, wa tark al-ahwā' wa al-bida' wa ta'zim hurumāt al-mashāyikh wa ru'yat a'dhār al-khalq, wa al-mudāwamat 'alà al-âwràd, wa tark irtikāb al-rukhas wa al-ta'wilàt. AlQushayrí, Risāla, 438; cf. al-Dhahabì, Siyar A 'lām al-Nubalā', XVI, 265; XVII, 249.

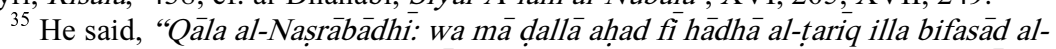
ibtidā'; fainna fasād al-ibtidā', yu'thiru fì al-intihā', "Sulami, Kitāb Tabaqāt al-Ṣüfìyya, ed. J. Pedersen (Leiden: E.J. Brill, 1960), 515.

${ }^{36}$ Al-Subkì, Tabaqàt al-Shāfì ‘iyya al-Kubrā, III, 170. 
through these Sufi masters that the connection between al-Sulami and the Baghdadi Sufi circle was strengthened.

Al-Nașrābādhì's relationship with al-Sulamī was firmly established, as both shared the same concern to collect prophetic traditions. It is also known that al- Nașrābādhi was considered a reliable (thiqa) transmitter. ${ }^{37}$ Their shared concern for hadith was shown, when both al-Sulami $\bar{i}$ and al- Naṣrābādhi were visiting Makka. According to the story, whenever they came across each other the latter would say, "Let's listen to hadiths!" According to al-Sulami, this was in 366/977, shortly before the death of Nașrābādhi in 367/978. In view of such an intimate relation, and considering the important status of the master within the mystical circle of Baghdad, it was through him that al-Sulami might have been able collect the mystical traditions for his Tärikh and Tabaqät al-Ṣüfiyya. It was through the direct contact with al- Nașrābādhì that al-Sulami learnt much about the historical background of the Sufi circle of Baghdad. This strong connection to the Baghdadi circle was not only significant for his collection of mystical sayings, most of which had been promulgated by the Sufi masters among the Baghdad circle; but this strong bond also explains that the spiritual path al-Sulami had undergone was genuinely connected to the Baghdadi sober type of Sufism.

\section{Curing Sufism from its Degraded Condition}

By considering various influences like the Malāmati background coming from Ibn Nujayd, the blend between Shäfi $\overline{\mathrm{i}}^{\mathrm{i}}$ fiqh and sober Sufism taken from Abū Sahl al-Ṣu'lūki and Abū al-Qāsim al-Naṣrābādhi, we are quite certain to say that al-Sulami as a Sufi belonged to a moderate type of Sufism that we may call it "Sunnite Sufism". The tendency to link Sufism with the Shari'a might have become the new wave of orthodox scholasticism towards the formation of mystical theology, considering the degrading condition of the contemporaneous climate, including Islamic spirituality. In the hands of al-Sulami the Baghdadi tradition was molded into a unique mystical school of Nishapur because the spirit of making a blend between Sufism and Shari' a remained the focus within the traditionist background of the Nishapuri Sufis. In addition, an extent influence from the neighboring regions of the eastern provinces might have contributed to the spirit of establishing moderate Sufism to remain alive also, especially among the Hanafites in Transoxiana. We may note Abū Bakr al-

\footnotetext{
${ }^{37}$ Al-Sha'rānī, Al-Ṭabaqāt al-Kubrā. Cairo: np, 1897, vol. i, 122.
} 
Kalābadhi (d. 385/994) who remarked that his tendency to make a blend between Sufism and the Shari'a was due to the decay of Sufism. ${ }^{38}$

In order to cure Sufism from its degradation and to secure its good image, al-Sulami was connecting Sufism to orthodoxy through his magnanimous collection of prophetic traditions. In his Kitāb Jawāmi ' Adāb alSüfiyya, edited by E. Kolberg, for example, he tried to enroot Sufism in the traditions of the prophet Muhammad. He did this in several treatises like Uyüb al-Nafs wa Mudāwamātuhā, Kitāb al-Samā‘, and al-Risāla al-Malāmatiyya. All treatises show his responses to the environment that was in favor of Sufism, but in which Sufism was facing degrading problems that demanded immediate responses. The responses took the shape of writing certain treatises to provide answers and clarifications. The task of al-Sulami's works was to harmonize Sufism with orthodoxy as expressed by the traditionists (ahl al-sunna), a popular name for the adherents of the Shäfi'ite School in Islamic law.

In conclusion, al-Sulami was being a Sufi traditionist as wished by alSari al-Saqați to his nephew al-Junayd, when he left al-Sari to quench the advanced spiritual guidance from al-Harith al-Muhāsibī. At this occasion al-Sari prayed that his nephew will have become a Sufi traditionist (șähib al-hadith șüfî), not the extatic Sufi (șüfi șăhib hadith). ${ }^{39}$ In fact, this wish represents the nature of the sober type of Junaydian Sufism, upon which we may call "the Sunnite Sufism". It was from the line of such a sober type of Sufism that alSulami inherited the spirit of the Baghdadi Sufi circle from either al-Ṣu'lūki or al-Nașrābādhì.

\section{The Contentious Haqā'iq al-Tafsìr}

Representing of the extended proponents of the Baghdadi Sufi circle in Nishapur, the Haqā'iq al-Tafsír was one of Sulami's greatest achievements. However, it became quite controversial as there had so much criticism to this

${ }^{38} \mathrm{He}$ wrote that the decay of Sufism was to be his main motivation to compose the book. It is true that he lived in environment favorable to Sufism, but one in which Sufism began to deteriorate as he said that at that time the profound reality (tahqiq) became embellishment (hilya) and verification (tasdiq) only became ornament (zina), whereas claimants took their claims from someone unknown. Thus, up to his era, Sufism accordingly had lost its sense, only the name remained. See al-Kalābadhi, Al-Ta 'arruf li Madhhab Ahl al-Tașawwuf, first ed. A.J. Arberry (Cairo: Maktabat al-Khanji, 1933), 4.

${ }^{39}$ Al-Makki wrote, "Wa haddathūnā 'an al-Junayd qāla idhà qumtu min 'indi Sarí

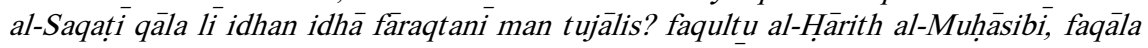
na'am khudh min 'ilmihi wa adabihi wa da' 'anka tashqiquahu lil kalām, wa raddahu 'alā al-mutakallimīn, qāla falammā wallaytu sami 'tuhu yaqūlu ja 'alaka șạhib ḥadith șüfiyyan, wa lā ja alaka șüfiyyan șạhib ḥadith." Al-Makkī, Qüt al-Qulüb (Cairo: al-Maṭba'a alMișriyya, 1932), II, 35. 
tafsir in the later period. To understand the contentious elements of this tafsir, we have to say that such might have been aroused by the use of the transmitted exegetical materials, in which al-Sulami incorporated the hadith in addition to mystical sayings of the previous Sufis among the täbi'in and the following generations to shape his mystical commentary. In the latter category, al-Sulami collected comments on notable Sufis and revered figures among his predecessors ranging from Ja'far al-Ṣādiq to one of al-Sulami's own teachers, Abū al-Qāsim al-Nașrābādhì (d. 367/978). The aim of conducting a traditional style of exegetical writing represented by the Haqā'iq al-Tafsir might have been what Kohlberg mentions as spreading the knowledge of Sufism to the general public. ${ }^{40}$ This aim is obvious in al-Sulami's introductory remarks of the tafsir, as he decided to put aside the outward sciences of tafsir by providing the opinion (maqāla) of the masters of the knowledge of the profound reality (ahl al-haqiqa); hence, he collected their sayings and arranged those sayings in accordance to the order of the chapters and verses of the Holy Scripture. In addition, the way he composed the book by omitting most chains of transmission certainly incited controversy concerning his intellectual credit of being a reliable transmitter.

From his own huge collection of Sufi sayings al-Sulami was able to compose a compilation of mystical traditions for the commentary of the Qur'ān. The most probable factor that put this work under harsh criticism, even from his fellow Shäfi'ite adherents, was that he employed the traditional method of riwāya in providing specific commentaries on the Qur'anic verses that only sustained symbolic interpretations. These symbolic interpretations should be classified under the method of ta'wil, which transpasses the boundaries of the approved formal interpretive accounts referred to by the term tafsir. Hence, both his aim to compose Qur'anic commentary beyond the formally and normally literal meanings of the Qur'anic verses and the contentious title of his book of Qur'anic commentary has certainly caused many scholars to criticize him and his book later. Among the outspoken critics some also accused alSulami of having made false attributions to certain revered figures like Ja'far alSaadiq, to which these false attribution in turn would have been raising the problem of transmission in his traditional style of interpretation, ${ }^{41}$ as well as challenging his intellectual credibility. ${ }^{42}$

${ }^{40}$ Al-Sulamī, Jawāmi $\bar{A} d \bar{d} b$ al-Șüfiyya wa 'Uyūb al-Nafs wa Mudāwamātuhā, Edited with an introduction by E. Kohlberg, The Max Schloessinger Memorial Series no. 1 (Jerusalem: Jerusalem Academic Press, 1976), 8.

${ }^{41}$ The fact that al-Sulami's works, especially the Haqā'iq al-Tafsir, lack indicating the definite source, as sometimes he simply narrates qila, meaning 'it is 
On the ground that the Haqa'iq al-Tafsir is responded by the later generations after al-Sulami's demise to be controversial work of tafsir, the further questions are what reasons to explain behind such a controversy and does it truly bear Shi'ite flavor as al-Sulami was also being related to the Bătiniyya? The answer of these two question will be highlighted by some findings that being composed by a Sufi traditionist like al-Sulami the Haqa'iq al-Tafsir should also represent a Qur'anic commentary laid down under the sound principles of Sunnism.

\section{A Confusing Context}

The first point to explain on what reasons behind the contentious nature of the Haqā'iq al-Tafsir is that the work was composed within a confusing context of what the Arabic term tafsir denotes. By analyzing the introductory section of the Haqa'iq al-Tafsir, we can clearly define the author's intention on what kinds of exegetical materials he had been able to collect into his compendium. However, it remains unclear how he envisaged the place of his own collection within the existing types of tafsir. It seems that al-Sulami, who was very much aware of the scope of the extent genres of tafsir, had already excluded his piece from the extant kinds of Qur'anic interpretation and Qur'ānic studies. In addition, from the title given to al-Sulami's collection we may also conclude that the term tafsir, employed in the title "Haqā'iq alTafsir", might have been applied to any sorts of collections comprising various kinds of exegetical traditions of Qur'ānic interpretation, including the esoteric approach. A supporting argument for attaching the term tafsir to the collection of traditionally transmitted materials can be discerned in the view of Abū Nașr al-Qushayri, who lived in Nishapur about two generations after al-Sulami, that the exegetical method of tafsir was conducted by way of following (ittibā) and direct communication $\left(\operatorname{sama}^{-}\right){ }^{43}$

We may thus say that al-Sulami was certainly a collector of exegetical traditions. He was able to quote a variety of exegetical approaches and related them to the names of early Sufis as the principal sources, not to his own name

mentioned' with no reference to his sources contributed to discredit his ability as a muhaddith.

${ }^{42}$ See Ibn Taymiyya, Minhāj al-Sunna al-Nabawiyya fì Naqụ Kalām al-Shī ‘a wa al-Qadariyya, ed. Muḥammad Rashād Sālim (Cairo: Mu'assasa Qurțùba, 1962), IV, 155.

43 Al-Zarkashì, Al-Burhān fí̀ 'Ulūm al-Qur'ān, Ed. Muḥammad Abū al-Faḍl Ibrāhīm (Cairo: Dār Ihyā' al-Kutub al-'Arabiyya, 1957), II, 150; al-Suyūṭ̂, Al-Itqān fì 'Ulūm al-Qur'ān, ed. Muhammad Abū al-Faḍl Ibrāhīm (Cairo: Maktaba al-Mashhad alḤusayni, 1967), IV, 168. 
as a compiler. Thus, if the early Sufis produced a kind of ta'wil within the framework of allegoric and symbolic interpretations, so this kind of ta'wīl was not al-Sulami's own inference. Al- Sulami did not perform istinbāt, in the sense of "inferring a meaning from the texts by way of exerting one's mind and using the strength of one's innate disposition", nor solely producing sorts of ta'wil. ${ }^{44}$ His task as an exegete is merely presenting varieties of opinion while instigating readers to choose the most preferable meaning on their own stances. Hence, he merely played his role as a conveyor of such mystical traditions. Consequently, by judging the title of the book and his method of compilation, we can say that exerting exegesis by way of presenting a collection of traditions was certainly included into the category of tafsir. However, unlike al-Tabari who consistently provided the complete chains of transmission, al-Sulami often omitted the isnād, for which he was often criticized for such omissions.

The contentious nature of al-Sulami's compilation should certainly be reduced to the fact that he unnoticeably play important role in selecting the mystical traditions by way of conducting censorship of any obsolete views among certain early Sufis' opinions. The absence of a detailed exposition on the mystical doctrine of the emanative process of creation ${ }^{45}$ shows us that he conducted a certain form of censorship in the process of selecting the mystical traditions. This censorship was taken because the detailed elaboration of the doctrine of Muhammadan light incites a slightly Shi'ite flavor that does not suit both rational and traditional perspectives of the Ash'āite theological system. ${ }^{46}$

Nevertheless, it still remain confusing to classify the Haqa'iq al-Tafsir under the methodological framework of $t a f s \bar{i}$, as we understood the term today to mean an objective interpretation of the Qur'anic verses. The reason to

${ }^{44}$ He wrote, "istikhrāj al-ma‘āni min al-nușuss bifarți al-dhihni wa quwwat al-

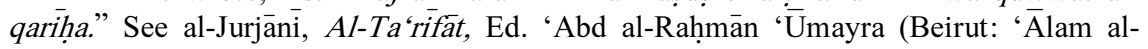
Kutub, 1987), 44.

${ }^{45}$ This interpretations refers to the mystical doctrine of Muhammadan light promulgated by Sahl al-Tustari, in addition to Ja'far al-Ṣādiq as mentioned by Sulami in Haqa'iq al-Tafsir, II, 343. However, unlike al-Tustarī who explained the doctrine in his own collection (see Tustarī, Tafsìr al-Qur'ān al-Ażim (Cairo: Dār al-Kutub al-'Arabiyya al-Kubrā, 1911), 68; see also pages 40-41). Al-Sulami quoted Sahl al-Tustari as well as Ja'far without details in his Haqā'iq al-Tafsiri, II, 45.

46 The supposedly Shi'ite origin of the doctrine of Muhammadan light was

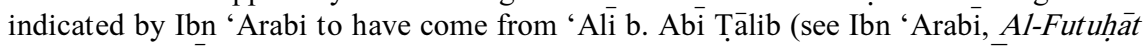
al-Makkiyya fi Ma 'rifat Asrār al-Malakiyya (Cairo: al-Hay'a al-Mișriyya al-'Āmma li alKitāb, 1972), II, 361). In Sulami, this view was received through Ja'far. By the growing tendency of enrooting Sufism in Sulami's works, the doctrine of the emanative process of creation was considered obsolete, compared to the Ash'arite's theory of creation of the world out of nothingness. 
exclude Sulami's interpretation from the formal category of tafsir is based on the primary consideration that the exegetical materials collected by al-Sulami were laying outside the common exegetical genres generally conducted by scholars of his time. This may be understood from al-Sulami's own explication in his introductory section of the book that he only provided "comprehension" or "understanding" derived from a certain group of people he indicated with the epithet "the people of profound reality" (ahl al-haqiqa). According to al-Sulami, such a compilation had been neglected as there were scarcely any collections of Sufis' sayings and opinions. Thus, he specifically excluded his collection from the so called a scholarly genre of "outward sciences" that commonly deserved the term tafsir. In summary, he actually did not compose a general exegetical work commonly called by term tafsir, but an esoteric one for a different class of readers, viz. very restricted spiritual elites, on the basis of the precaution that the contents would have been misunderstood by general populace.

\section{The Borderline Category}

On the basis of the above confusing context to determine the meaning of tafsir as understood in the era of al-Sulami, we move on to proceed our second assumption that perhaps one would understand that the term tafsir was put by al-Sulami into a borderline category which could be flexibly suited to any kinds of comprehension. However, the use of the term tafsir for a book comprising esoteric exegesis became the object of various attacks from differing points of views promulgated by his critics, either among his contemporaries or more particularly among the critics of the following generations. Hence, as it was mentioned earlier by Ibn Habīb al-Naysabūri (d. 406/1015), ${ }^{47}$ it will be better to situate the diffusion of the Haqä'iq al-Tafsir under the degrading scholarly climate of Nishapur, in which contemporary ulamā' could not distinguish between the concepts of tafsir and ta'wil. Besides, it was also clear that Ibn Habib's statement implied to a century-long period of transition from the end of formative period of Islamic thought that brought the triumph of Sunnism. ${ }^{48}$ The era was marked politically by the extant but slowly diminishing influence of the

${ }^{47}$ His grievance to the degrading scholarly climate of Nishapur at the turn of the $5^{\text {th }} / 11^{\text {th }}$ century was about the scholars' ignorance of distinction between tafsir and ta'wìl, as well as the way to recite the Qur'an properly and to know the meaning of its verses, release from hard work, deep thinking, as well as their hatred of being questioned. This statement is quoted by al-Zarkashì, Al-Burhān fì 'Ulüm al-Qur'ān, II, 152.

${ }^{48}$ The end of formative period of Islamic thought is marked by the demise of alAsh'ari (d. 935) and al-Măturidi (d. 944). W. Montgomery Watt, The Formative Period of Islamic Thought (Edinburgh: Edinburgh University Press. 1973), 316. 
Buyids on the central 'Abbāsid caliphate in Baghdad, contrary to the strengthening position of the Seljuks in Khurasan. ${ }^{49}$ This political situation brought about the victory of traditionists within the development of Islamic scholasticism.

By setting aside any dubious schismatic approach, the degrading scholarly climate illustrated by Ibn Habīb al-Naysabūri might have been referring to the narrowing concept of tafsir that had been initiated by alMāturidi (d. 944), which marked the end of the formative period of Islamic thought along with the maturing Sunni theology. Al-Māturidi conceived tafsir to be "[Making] a scission (qat") that the intended meaning of a word (lafz) is such and such with a testimony before God that He entitled the word with such [a meaning]; if there is a definite proof, the meaning is valid; but if not, it will be an analytical interpretation (tafsir bi al-ra'y), which is forbidden;" whereas

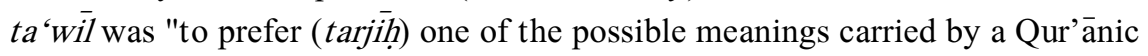
verse, but without scission ( $q a t^{\circ}$ ) [on that meaning] nor [requiring] a testimony to God." ${ }^{50}$

Looking to the above definitions, as a matter of fact, the distinction between the term tafsir $\overline{\text { and }}$ ta'wil was as yet unknown as there had been no certain objection to employ either the terms of tafsir, ta'wìl, or ma 'nä for any sorts of exegetical methods during the formation of Islamic thought marked by the demise al-Māturidi ca. 350 AH. Both tafsir and ta'wì had previously denoted the activities of interpreting the Holy Writ. In this general sense, alFarrā' (d. 210/825) named his book Ma'āni al-Qur'ān, while Sahl al-Tustarì (d. 283/896) named his mystical interpretation Tafsìr al-Qur'ān al-Azín, and finally al-Tabari (d. 310/923) named his compilation with the title Jämi alBayān 'an Ta'wīl ày al-Qur'ān. All of them were classical exegetes, who lived before al-Māturidi. There had been no objection to name exegetical collections to any names during the classical period, hence the exchangeable terms of ta'wìl, tafsiri, or ma'nā were similarly denote the same meaning of Qur'anic interpretation. Such an unscrupulous usage of various exegetical methods was clear in the opinion of $\mathrm{Abu}$ ' Ubayd (d. 225/840), who had noted that both terms were synonymous. ${ }^{51}$ Al-Suyūtî, who cited Abū 'Ubayd's opinion in his al-Itqān

${ }^{49}$ See Frye (1975), 228.

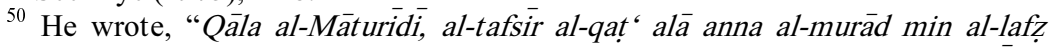
hādhā, wa al-shahādatu 'alā Allāh annahū 'anā bi al-lafẓi hādhā; fa in qāma dalìiun maqtù ' bihi fa șahịh, wa illa fa tafsirun bi al-ra'yi wa huwa al-manhiyy 'anhu. Wa ta'wì tarjị̣u ạ̣adi al-muhtamilāt bidūni al-qat" wa al-shahāda 'ala Allāh." Al-Suyūṭi, AlItqā̀n fì 'Ulüm al-Qur'ān, IV, 167.

${ }^{51}$ Al-Suyūtị, Al-Itqān fì 'Ulüm al-Qur'ān, IV, 167. 
continued to explain that some people ( $\mathrm{qawm}$ ) began to disagree with such a simple generalization in about one and a half centuries after the death of $\mathrm{Abu}$ Ubayd. At that moment the problem reached the ears of Abu al-Qāsim Muhammad b. Habīb al-Naysabūri (d. 406/1015) who asserted that the distinction between the two terms was in need of being explicated in more details. ${ }^{52}$ However, the long span of more than a century from the introduction by al-Màturidi and its application in the era of al-Sulami is also too long to ignore in the development of Qur'ānic hermeneutics. Al-Suyūṭ $\bar{i}$ himself mentioned al-Măturidi's opinion, which may really have introduced the extant technical differences between the terms tafsir and ta'wil since the near end of the classical period. However, the remote area of Samarkand, where al-Māturidi spent most of his life, in addition to his unknown scholarly career as well as his ascetic life, ${ }^{53}$ may have contributed to the persistent ignorance of this shifting concept.

The most important contribution initiated by al-Māturidi to the development of Qur'anic interpretation is that he had outlined a clear demarcation between tafsir and ta'wìil. It was certainly al-Māturidi's technical definition of the term tafsir, viz. to be the scission (qat) of the intended meaning of a word (lafz), which was indeed very important contribution in narrowing down the technical definition of the term tafsir. Its meaning from then on had become restricted to the interpretation of Qur'ānic verses applying the method of "ibāra which means, according to Abū Zayd, "to limit the meaning, making the meaning locked (mughlaqa) and reaches its end." immediate impact of such a restriction to the concept of tafsir was that the activity of interpreting the Qur'anic verses is to be conducted within a more scriptural approach. In this approach, the tafsir for a verse takes its proof by linking the verse to a sequential search starting with parallel Qur'ānic passages, and then continuing with the Hadith. If there were no Qur'anic parallels, nor anything to be traced in the other scriptural sources, the interpretation is to be taken by way of ijtihàd. A detailed elaboration of such a hierarchic procedure can be found in the work of a medieval traditionist like Ibn Taymiyya (d. 728/1328) and also in writings of his disciple Ibn Kathï (d. 774/1373). ${ }^{55}$ In fact,

${ }^{52}$ See al-Zarkashìi, Al-Burhān fì 'Ulūm al-Qur'ān, II, 152.

${ }^{53}$ See W. Madelung (1986), "Al-Māturidì" in $E P^{2}$, vi, 846a.

${ }^{54}$ Abū Zayd, Hākadhā Takallama Ibn 'Arabì (Cairo: al-Hay'a al-Miṣriyya al‘'̄mma li al-Kitāb, 2002), 139.

${ }^{55}$ See Ibn Taymiyya's answer to the query on the best way of interpretation (Ibn Taymiyya, Majmū Fatāwā, edited by 'Abd al-Rạ̣mān b. Muḥammad b. Qāsim with the assistance of his son Muhammad b. 'Abd al-Raḥmān and introduced by 'Abd Allāh b. 
this hierarchic procedure laid down the principles of exegesis in the later development of Sunnism. It was through such an emendation that the narrowing sense of the term tafsir would be standard within the scholarly milieu of the Sunnite in the formation of Islamic orthodoxy.

Consequently, analytical interpretation by way of exercising ijtihäd might have been permitted as long as the explication of the meaning of a verse could not be found within the Qur'ānic parallel or its explanation in Prophetic traditions. Moreover, any other kinds of interpretation will be posited outside the boundary of the term tafsir. To mention some examples of these kinds are exegetical methods conducted by extreme jurists, theologians, philosophers, and the Sufis. All of kinds of interpretations would only be classified under the category of ta'wil.

A further impact of the formation of orthodoxy within the scholarly atmosphere of Muslim scholasticism, especially the Sunni religious group, was the distinction between the approved method of tafsir that belonged to the group of traditionists, i.e. the orthodox followers who often named themselves as "the People of Tradition", "ahl al-sunna", or "ahl al-hadith"; and the condemned method of ta'wil that was attributed to the heterodox group, the "ahl al-bida", among whom the Sufis were also included, as well as the proponents of the condemned religious schools. ${ }^{56}$ Political struggle may also have contributed significantly to this growing dichotomy between the approved group of intellectuals and the condemned ones. In fact, Sufis had actually been the object of condemnation since they were positioned into a marginal community, who used to remain aloof of the political sphere. And even if they

'Abd al-Muhsin al-Turkī (Riyaḍ: Wizārat al-Shu'ūn al-Islāmiyya wa al-Awqāf wa alDa‘wā wa al-Irshād, 1995), III, 311); Ibn Kathir's introductory section of his Tafsir on the same hermeneutical problem (Ibn Kathï, Tafsir al-Qur'ān al-'Azim, edited by Sāmi b. Muhammad Salāma (Riyaḍ: Dār Țayyiba, 1999), I, 7). Both exegetes shared the same principle of interpretation as they belonged to a master-disciple relationship despite their distinct affiliation in madhhab. For the hermeneutical theory promulgated by Ibn Kathir in the light of his teacher's ideas, see McAuliffe, "Qur'anic Hermeneutics: The Views of al-Tabari and Ibn Kathir," in A. Rippin, Approaches to the History of the Interpretation of the Qur'an (Oxford: Clarendon Press, 1988), 46-62; see also McAuliffe, Qur'anic Christians: An Analysis of Classical and Modern Exegesis (Cambridge: Cambridge Univ. Press, 1991), 71-76.

${ }^{56}$ The distinction between tafsir $\bar{i}$ and ta'wil was often developed as the difference between a literal and an allegorical interpretation, or a single and a multiple derivation of meanings. From sociological perspective, ta'wil seems to be "the other face of a text" (al-wajh al-äkhar li al-nașs) in the Islamic civilization of the Arabs. This consequently leads to consider ta'wìl reprehensible (makrüh) within the formal religious thought based on tafsìir (See Abū Zayd, Mafhūm al-Nașs: Dirāsa fì 'Ulūm al-Qur'ān (Cairo: Al-Hay'a al-Mișriyya al-'Āmma li al-Kitāb, 1993, 247). 
had been involved in certain political movements, such political participation would have been the reason to brand them as heretics. ${ }^{57}$

Probing deeper the Haqā'iq al-Tafsìir, Sulami's attempt to collect only mystical traditions for his exegesis of the Qur'ān (tafsir) may have been considered unusual in the eyes of tradition, since they were commonly limited the term tafsir only to sorts of rigid and literal approaches of interpretation. AlSulami tried to blend Sufism with the Shari'a that marks his works full of speculative ideas amidst the proofs of traditional sources. Such was not quite welcomed by traditionists who objected to the speculative ideas poured into their seemingly puritan line of thought. This would also underline the compound of the Haqā'iq al-Tafsir cannot be classified as strictly displaying a traditionist style of interpretation. ${ }^{58}$

\section{Discerning the Meanings of Haquiqa}

The need to trace the meaning of haqiqa within the atmosphere of scholarly thinking of the $5^{\text {th }} / 11^{\text {th }}$ century Islam is necessary in order to investigate the most probable reason why al-Sulami named his work Haqā'iq alTafsir, and how readers responded to such controversies in later periods. The only immediate information revealed from the introductory sections of alSulami's mystical compendium is that the author had intended the book to be a collection of accounts and sayings of the Sufi masters renowned the epithet mashāyikh ahl al-haquiqa. These Sufi masters were representing a group of people whom God had bestowed them the understanding of divine discourses. As the term haqiqa applied to an esoteric interpretation the investigation is to trace the meaning of the term haqiqa within the field of Islamic mysticism, and even within philosophical discourses of the surrounding milieu as well as scholarly culture developed at the time of the life of al-Sulami. Consequently, the term haqiqa had closely related to philosophical thinking as the term alHaqq was commonly used by both philosophers and Sufis to denote God. Besides, we may also relate the term haqiqa to a completely different concept as

57 The case of al-Hallaj's execution, for example, was embellished on his connection with the politically rebellious movement of the Qarmatiyya. See Massignon, The Passion of Hallaj. Mystic and Martyr of Islam, transl. from the French with a biographical foreword by Herbert Mason (Princeton: Princeton University Press, 1982), I, 200-201; III, 193-1944.

58 Al-Sulami's academic career showed a blended taste. His master in figh was Abū Sahl al-Ṣu'lūkí, who gave also a taste of mystical touch of Islamic law, in addition that al-Ṣu'lüki was also a direct disciple of Abu al-Hasan al-Ash'ari, who might have given a further influence in the field of speculative theology. See Watt, The Formative Period of Islamic Thought, 312. 
it was also applied in the general field of Qur'anic exegesis from a linguistic approach (as for example we may compare haqiqa to majaz). It might be on the basis of such a linguistic approach that the Haqäiq al-Tafsir became the target of criticism and controversies after Sulami's demise.

The term haqiqa within the mystical perspective suggests a sense of "profound reality to which only experience of union with God opens the way". 59 Then, the closest explanation of this mystical sense, according to Louis Gardet, can be found in al-Hallāj's concept of divine names as quoted in al-Sulami's Tabaqāt al-Ṣūfiyya. Al-Ḥallāj said, "Divine names are [merely] a name from [the point of view of] comprehension (idrakk), whereas from the point of view of God the Real (al-Haqq) they are a reality (haqiqa)". ${ }^{60}$ From this stance, al-Hallāj concluded that everything real has an essential reality. Thus, the term haqiqa should be differentiated from Haqq as like the abstract and the concrete: "reality" and "real", Deity and God. ${ }^{61}$

Furthermore, from the stance of Islamic mysticism haqiqa can be differentiated from the term shari'a. Al-Qushayri as Sulami's junior contemporary in Nishapur defined haqiqa as the concept of witnessing Lordship (mushāhadat al-rubübiyya), ${ }^{62}$ which is coupled with shari' ${ }^{\circ}$ meaning the perseverance of worship (iltizām al-'ubūdiyya). ${ }^{63}$ From such a distinction, the term haqiqa leads to the meaning "a profound reality which remains immutable from the time of Adam to the end of the world." ${ }^{64}$ Such a mystical concept, according to Gardet, is juxtaposed to shari $\bar{i}^{\circ}$, which denotes reality that can undergo abrogation and changes like ordinances and commandments. ${ }^{65}$ However, the distinction between haqiq a and shari $\bar{c}^{\prime} a$ cannot be reduced to mere opposition, because one completes the other, as Gardet also underlined the

${ }^{59}$ L. Gardet, "Hakika," in $E F^{2}$, III, 75a.

${ }^{60}$ Al-Ḥallāj said, "Asmāe' Allāh Ta'āla min haythu al-idrāk ism, wa min haythu al-Ḥaqq haqiqua.” Al-Sulami, Tabaqāt al-Süfiyya, 309.

${ }^{61}$ Massignon, The Passion of Hallajj, III, 76-77; see also Massignon, Essays on the Origins of the Technical Language of Islamic Mysticism, transl. Benjamin Clark (Notre Dame: University of Notre Dame Press, 1997), 28.

${ }^{62}$ Al-Qushayri related the concept of mushāhada to the term mudānāh literally means "adhere to religion". Accordingly, there are three hierarchic levels of manifestation: (1) mushăhada bi al-haqq, to witness something with the argument of unity (2) mushāhada li al-ḥaqq, to see God in something, and (3) mushāhada al-haqqq, to see God in concealment with no description. See Qushayri, Arba' Rasā'il fí al-

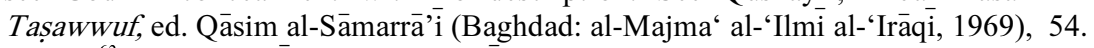

${ }^{63}$ Al-Qushayrì said, "al-Sharí'a amrun bi (i)ltizām al-'ubūdiyya, wa al-ḥaqiqua mushāhadat al-rubūbiyya." Al-Qushayrì, Al-Risāla al-Qushayrìyya fí 'Ilm al-Tașawwuf, 82.

${ }^{64}$ L. Gardet, "Hakika" in $E P^{2}$, III, 76 b.

${ }^{65}$ L. Gardet, "Hakika" in $E P^{2}$, III, 76b. 
relation between bạtin and zăhir. Thus, both concepts must be understood in a mutual correlation. This was also noted by al-Qushayri who stated there must a reciprocal relation between the two concepts, in which haqiqa is to be strengthened by shari ${ }^{\circ} a$, while at the same time shari ${ }^{\circ} a$ should be endorsed by haqiqa in order to achieve perfection. ${ }^{66}$

Similarly, a philosophical basis for such a parallel relation between haqiqa and sharī'a might have been inferred from Platonic philosophical concept of the world of ideas. The closest reference for such Platonic concept within the development of mystical thinking of the post classical Sufis of the $5^{\text {th }} / 11^{\text {th }}$ century may have been compared to some related concepts within the philosophy of Ibn Sina (d. 428/1037). This seems to be indicated by al-Jurjān̄̄'s explanation of the philosophical meaning of the term in his al-Ta'rifat. AlJurjānī defined the term haqīqa al-shay' to mean "the quiddity of a thing: the thing as it is in itself." Consequently, haqiqa is not the thing existing, but the essence of the thing in as much as it exists, or the real nature in absolute intelligibility. In close relation to the preceding meaning, the term al-hakika al'aqliyya means, according to al-Jurjāni, "the exact conception of a thing." ${ }^{67}$ Consequently, it can be concluded that haqiqa suggests the meaning of both reality and intelligibility within Platonic dichotomy between a thing and its image.

If we apply the preceding mystical and philosophical analyses to the title of al-Sulami's compendium, the Haqiq a al-Tafsir, we may read the conclusion that the collection of sayings and accounts of the Sufi masters was not an interpretation of the type commonly perceived by the ulamā' of the time. AlSulami's collection of mystical traditions was certainly esoteric, claiming to present the essence or profound reality of the Qur'anic verses rather than their formal understanding in the exoteric senses. His collection of mystical traditions referring to a number of Sufi individuals was generally esoteric comprehension resulting from mystical experiences in the form of mukāshafat. ${ }^{68}$

${ }^{66}$ Al-Qushayrī continued to say, "wa kullu shari 'atin ghayru mu'ayyadatin bi alhaqīqa fa amruhā ghayru maqbūl, wa kullu haquiqatin ghayru muqayyadatin bi al-sharī a fa amruhā ghayru maḥsūil.” Al-Qushayrì, Risāla, 82.

${ }^{67}$ Al-Jurjānì, Al-Ta 'rifăt, Ed. 'Abd al-Raḥmān 'Ūmayra. Beirut: ‘'̄lam al-Kutub, 1987., 123.

${ }^{68}$ According to al-Qushayri, mukāshafăt is higher than mushāhada. In this sense, the term mukäshafa bi al-ilm is defined to be "reaching clarification of truth in understanding" (tahqiq al-iṣāba fi al-fahm). Besides, according to al-Qushayri the Sufis could also attain a degree of unveiling in a mystical state (mukāshafa bi al-hāat) and the unveiling in an unexpected concurrence (mukāshafa bi al-wajd). See al-Qushayrì, Kitāb

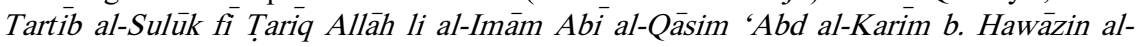


Thus, the act of unveiling what is hidden, which is perceived to be the general principle of tafsir $\bar{i}$ denoted either by the Arabic verbal root of $s$ - $f-r$ or its inverse form $f-s-r$, but in this case a mystical interpretation is based on the Sufis' unveiling of their mystical experience.

In the end, a book called a tafsir, but based on such profound mystical experiences had certainly classified under a specifically distinct perspective within the filed of Qur ānic interpretation. The term tafsir employed by alSulami as read in the title of his collection does not differ from the general books of tafsir only on a representation of the compiler's traditional approach by way of collecting mystical traditions from the previously sufi figures elaborating their Qur ${ }^{\circ}$ anic comprehension. Thus, the Haqiqa al-Tafsir $\overline{\text { in }}$ is called a tafsirin a sense that its main sources of interpretation are transmitted materials of sayings and opinions of the previous Sufis, viz. riwaya. However, in addition to its traditional style of tafsir bil-riwāya, the extant esoteric understanding poses some slight glances out of the boundary of "the sciences of the outward" (al- 'ulüm al-zähira), in which the main objective of the Haqiqa al-Tafsir was to provide another kind of tafsir out of its common category, viz. to bear the traditions of "the People of Reality (ahl al-haqiqa). Thus, the title of the book, indicated that this was not a tafsir $\overline{\text { of }}$ the usual type, but a specific collection esoteric materials far beyond what had been generally suggested with the term tafsir $^{-}$in its formal sense. ${ }^{69}$

We may assume that al-Sulami was aware of taking the risk in naming his collection with the phrase "Haqa'iq al-Tafsir" as both terms tafsir and haqiqa had received different technical senses within various branches of Islamic traditional sciences. Had we perceived the term haqiqa within the field of interpretation of the Qur'ān (ilm al-tafsir) as well as Rhetoric, the term haqiqa was perceived to mean "basic, divine, and definite meaning" which lays in a juxtaposed position to the so called allegoric meaning (majaz). ${ }^{70}$ This might be the point of controversy addressed by later critics to al-Sulami's Haqā'iq alTafsir. Since the field of 'ilm al-tafsirir is the common approach to measure the validity of Qur'anic intepretation within the Sunnite academic atmosphere.

Qushayrì (d. 465). Transl. and ed. by Qāsim al-Sāmarrā', In al-Sāmarrā'ì. Theme of Ascension in Mystical Writings: a Study of the Theme in Islamic and non-Islamic Writings (Baghdad: National Printing and Publishing Co., 1968), 54.

69 The quotation of the definition tafsirir promulgated by al-Māturidi can be read in al-Suyūtịi, Al-Itqān fí 'Ulüm al-Qur'ān, vol. iv, 167, which might have become the starting point of its narrowing sense held by the Sunnite representing the majority of the Muslim umma.

${ }^{70}$ In this sense, Ibn Taymiyya composed a treatise titled al-haqiqua wa al-majāz (ms. coll. Rashid Rida, Cairo) see L. Gardet, "Ḥakika," in $E F^{2}$, III, 75a. 
Then, it will not be surprising that so much criticism was addressed to blame alSulami's Haqā'iq al-Tafsir. The controversies were also fueled by a lack of clear understanding that the book was written skillfully by a Sufi exegete as well as Sunnite traditionist who had been educated under the influence of the Malāmatiyya movement. In conclusion, the term Haqā'iq al-Tafsir might not properly titled for such an esoteric commentary on the Qur'an under the perspective of ilm al-tafsir, but Qur'ānic interpretation beyond its formally existing exoteric meanings.

\section{The Principles of Interpretation}

Al-Sulami's clear outline of his method of mystical interpretation is based on solid bases of arguments within Islamic traditional thinking. The most fundamental query that he tried to answer was whether the Prophet had received revelations in other forms than the Qur'ān. He answered by quoting an

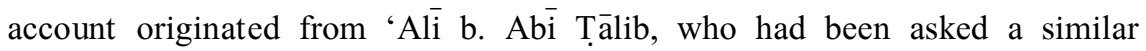
question. "Ali said, "No, by God who splits seeds and creates the living creatures, [this will happen] only if God will grant mankind the understanding of His Book." "71 This hadith clearly mentions the possibility that God is granting the understanding of the Qur'ān through some kinds of inspiration. On the basis of such a traditional account on the possibility of receiving "inspired divineknowledge", we may classify this kind of knowledge as the inner understanding (bätin). Al-Sulami also mentioned another tradition to frame the possibility of bearing fourfold meanings of Qur'ānic verses quoted from Ibn Mas'ūd. According to this tradition, the Prophet had said, "The Qur'ān was revealed on seven letters (ahruf), for every verse there are the outward (zahr) and the inward (batn); whereas every letter (harf) has a limit (hadd) and a point of ascent (matla $).{ }^{172}$

71 'Alì said, "lā, wa allādhì falaqa al-ḥabbata, wa bara'a al-nasama illā an yu'tiya Allāh 'abdan fahma kitābihi". This account was conveyed through Muhammad b. 'Abd Allāh b. Quraysh, al-Ḥasan b. Sufyān al-Fasawīi, Abū Mūsa al-Anșārí, 'Áb̄ās al-Qurashī,

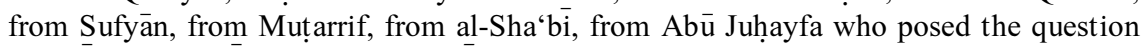
to 'Ali (Al-Sulamī, Haqā'iq al-Tafsìir, I, 20).

72 The prophet said, "Innā al-Qur'ān unzila 'alā sab 'ati ahruf, likulli àyatin minhu zahr wa batn wa likulli harfin hadd wa matla:" The hadith was conveyed through the following authorities: 'Abd Allāh b. Muhammad b. "Ali b. Muhammad b. Ziyād alDaqqāq, from Muhammad b. Ishạā, from Ishāā b. Ibrāhīm al-Ḥanḍali, from Jarīr, from Wạșil b. Ḥibān, from Ibn Abì al-Ḥudhail, from Abū al-Aḥwaṣ, from 'Abd Allāh b Mas'ud, from the Prophet (Al-Sulami, Haqā'iq al-Tafsìi, I, 21; al-Ṭabarāni, Al-Mu'jam al-Awsat, ed. Maḥmal-Ṭaḥhān (Riyadh: Maktaba al-Ma'ārif, 1985), I, 230-232). 
The above two traditional accounts were crucially fundamental to justify what al-Sulami collected amidst the traditions of "the people of the profound reality" (ahl al-haqā'iq). In al-Sulami's view, these people were the chosen specialists. They were a group of people who received understanding of divine discourse (ahl al-fahm likhitäbihi), as they were bestowed knowledge of the subtleties of Divine entrusted custody (al- 'älimūna bi lata'a'ifi wadā'i'ihi). ${ }^{73} \mathrm{Al}$ Sulami classified two occassions by which ahl al-haqa'iq receive divine knowledge: firstly, that God displayed (fataha) to them parts of the subtleties concerning divine secrets and [esoteric] meanings (ma'ānì); or secondly, that God may also make to appear (sanaha) to them parts of the wonder of his Book. However, nobody could speak about the [complete] essence of His profound reality (haqiquat haqā'iqihi). Each of them could only tell about a small portion of it as it is appropriated for them to understand. Thus, the discernment revealed to the Sufis, according to al-Sulami, was unable to cover the entire understanding. ${ }^{74}$

Such an elusive understanding exclusively belonging to the ahl al-haqiqa fell outside the boundary of the commonly known concept of comprehension called by the term 'ibära. As indicated earlier, such an understanding could not be easily attached to the exegetical method denoted by the term tafsiri, since alMātūridi promulgated a narrowing sense of the term tafsir and placed it in a juxtaposed position with the term ta'wil, to include all kinds of exegetical methods not covered by the term tafsir. Hence, tafsir $\overline{\text { in }}$ is attached to an objective interpretation in order to gain a standard and formally intended meaning as desired by God, the speaker of Qur'ānic discourse, in which it is commonly provided for all the hierarchically accepted categories of thinking within Islamic community. Tafsir is generally aimed at providing explanations of the Qur'ānic verses in the most obvious and easiest way of comprehension needed by general reader ('awāmm). In an alternate position, ta'wìl is a surrogate or subtitute exegetical method provided for people who daringly desire higher levels of understanding. Following the fourfold division of the Qur'an promulgated by Ja'far al-Ṣādiq, such an alternate understanding resulted by way of ta'wīl may include higher levels of discernment by the method of ishära, as it is juxtaposed to the method of 'ibara. The method of ishära comprises two layers of understanding classified as subtleties (lat $\bar{a}^{-}$'if) and profound realities (haqáa'iq), which will be subsequently achieved only by the specialists (khawāṣs) among

\footnotetext{
${ }^{73}$ Al-Sulamī, Haqā'iq al-Tafsìir, I, 19.

${ }^{74}$ Al-Sulami, Haqà'iq al-Tafsir, I, 19.
} 
the saints (awliya $\bar{a}^{-}$) and those who were privileged with a higher degree of prophecy (nubuwwa). ${ }^{75}$

Tracing further on the origin of Ja'far's fourfold division of the Qur'ān, we may reach a genealogical linkage of traditional transmission originating in

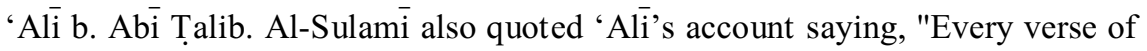
the Qur'an has a fourfold meaning: the outward (zāhir), the inward (bātin), the limit (hadd), and the point of ascent (matla)." "Ali further explained, " [firstly] the outward is the recitation (tiläwa), [secondly] the inward is the comprehension (fahm), and [thirdly] the limit is the explanation ('ibära), symbolic expression (ishära), as well as the legal rules of lawfulness (al-halāt) and prohibition (al-harām), and [fourthly] the elevating point (matla') as the final intention (murād) for his servant." "Alī further stated, "[God] creates [within] the Qur'ān [sorts of] explanation ('ibāra), symbolic expression (ishāra), subtleties (latán'if) and profound reality (haqa'iq). Explanation is for hearing $\left(\mathrm{sam}^{\prime}\right)$, symbolic expression is for intellect ('aqI), subtleties are for vision (mushāhada) [of divinity], and profound reality is for submission (istisläm)."76 This ideas, shared with the traditional Shi'ite interpretation, may have caused the accusation of al-Sulami's being associated with the Qarmati or Bătini organization. $^{77}$

For his collection of exclusively mystical sayings al-Sulami had put aside any categorical interpretations employing the method of "ibāra. He may have left out the "outward sciences" (al- "ulüm al-zāhira), ${ }^{78}$ because collections of the prophetic traditions of this type of interpretation had already been the concern of many other traditionists amongst his precursors and many of his contemporaries as well. The elusive content of his collection certainly was far removed from the need of the larger Muslim community. It was certainly a unique tafsir for a very limited circle of readers. It comprises only traditions of Qur'anic comprehension on the basis of the deepest level of understanding, i.e.

${ }^{75}$ The report was taken from Ja'far without any sufficient information about its chains of transmitters. Al-Sulami only mentioned the method of transmission with the phrase hukiya 'an Ja 'far b Muhammad meaning "reported" or "given an account" from Ja'far (Al-Sulamì, Haqà'iq al-Tafsìi, I, 22).

76 He asserted, "mā min àyatin illa wa lahā arba'atu ma ‘ānin: zāhir wa bātin wa hadd wa matla' qāla: 'al-zāhir al-tilāwa wa al-bātin al-fahm wa al-ḥadd huwa 'í̄àra wa ishāra wa ạ̣kām al-ḥalāl wa al-ḥarām wa al-matla' murāduhu min al- 'abd bihā wa ja'ala al-Qur'ān 'ibārat wa ishāratan wa lațā'if wa haqā̄iq fa al-'ibārat li al-sam 'i, wa l-ishārat li al-'aqli wa al-latā'if lil mushāhada, wa al-ḥaqā'iq li al-istislām. Al-Sulamì, Haqà̃'iq alTafsir, I, 22-23.

${ }^{77}$ This expression was later found in al-Dhahabi's critique to the Shaykh. See alSubkī, Tabaqāt al-Shāfi 'iyya al-Kubrāa, IV, 147.

${ }^{78}$ Al-Sulamí, Haqā'iq al-Tafsir, I, 19. 
the level of haqa' 'iq, the highest level of spiritual significances that come from the peak of mystical experiences.

\section{Scholarly Critique: From Apology to Accusations of Heresy}

The most probable absence of an immediate reaction to the Haqā'iq alTafsir $\bar{i}$ during al-Sulami's life time seems to be in line with the degrading socioreligious climate at the turn of the $5^{\text {th }} / 11^{\text {th }}$ century, as described by Ibn Habib (d. 421/1015) by his own statement as quoted in al-Zarkashi, "It is outstanding in our time that when some, ulama' are being questioned about the distinction between tafsir and ta'will, they will not succeed in doing so. They do not recite [the Qur'ān] well, and do not know the meaning of a chapter (sura), or [even] a verse of the Qur'ān..." ${ }^{\text {79 }}$ Besides, the period also shows a rupture towards a new development of Qur'anic interpretation. The line between traditionalist and rationalist thinkers began to be drawn at that time, and too between orthodox and heterodox factions within Muslim scholasticism, as this happened through various cases of "inquisition" (mihna).

The earliest criticism of the Haqā'iq al-Tafsir may have connected with the growing awareness of the distinction between the term tafsir and ta'wil, expressed by Ibn Habib al-Naysaburi, which was mentioned before. Almost a generation after the death of both Ibn Habīb and al-Sulami, a critical remark on the Haqa'iq al-Tafsir was addressed by a native Nishapuri among their junior contemporaries, Abū al-Hasan 'Alì al-Wāhidì (d. 468/1076). As an adherent of the Shäfi'ìte school of law and a Qur'ānic commentator as well as a traditionist, al-Wāhidi warned poeple to beware of what had been written by al-Sulami as he stated, "Abū 'Abd al-Rahmān al-Sulami composed the Haqā'iq al-Tafsiri, had he firmly believed [the book] to be a tafsir, he would have been committed heresy." ${ }^{80}$ By this conditional sentence, the statement should not be classified to be a harsh accusation of heresy to al-Sulami himself, but rather a warning for everybody not to consider esoteric commentary as an objective interpretation of the Qur'anic verses. The critic seems to imply that al-Sulami could be mistaken

${ }^{79}$ Al-Zarkashī, Al-Burhān fì 'Ulūm al-Qur'ān, II, 152. He wrote, "qāla al-Imām Abū al-Qāsim Muhammad ibn Habìib al-Naysābūrì: wa qad nabagha fì zamānina mufassirūn law su'ilū an al-farq bayna al-tafsir wa ta'wì mà ihtadū ilayh, là yuhsinūna al-Qur'ān tilāwa, wa là ya 'rifüna ma 'nā al-süra aw al-àya,..."

80 Al-Wāhidi asserted, "Ṣannafa Abū 'Abd al-Rahmān al-Sulamī Haqā'iq alTafsìi, fa in kāna qad i taqada anna dhālika tafsiran fa qad kafara.” Al-Subkī, Tabaqàt alShāfi 'iyya al-Kubrā, V, 241; Ibn al-Ṣalāh, Fatāwā Ibn al-Ṣalāh fi al-Tafsìir wa al-Hadìth wa al-Ușūl wa al- 'Aqā'id (Cairo: Idārat al-Ṭibā'a al-Muniriyya, 1929), 19; al-Suyūtí, AlItqān fì 'Ulüm al-Qur'ān, IV, 194-195. 
only in case that he classify his Haqa ${ }^{-}$iq a-Tafsir as an objetive interpretation intended by the term tafsir, as such might lead to an act of heresy.

Such a warning had been growing from awareness of the dangerous impact of publicly diffusing the mystical interpretation. This also probably led the Sufis to be accused of committing Bătini $\bar{i}$ ta'will. ${ }^{81}$ In fact, the difference between Sufis and the Bătinīs was barely known to laymen. Al-Wāhidī's statement may contribute theological issues before it was theoretically clarified by al-Ghazāi $\bar{i}$ in his Faụa'ị al-Bătiniyya (the Ignominies of the Bătiniyya), which sociologically refers to various sects of the Shi'ites from time to time. ${ }^{82}$

The difference between the Sufis and the Bạtiniyya was consisted primarily by the former's attestation of the applicability of the zăhir meaning despite their advance steps to uncover spiritual significances of the Qur'anic verses. It was on the ground of accepting the zăhir that the Sufis were safe from being accused of heresy as it is warned by al-Wāhidi. On the contrary, the Bătini only believed in the inward meaning of the Qur'anic verses, on the basis of which their main goal was to obliterate the shari ${ }^{\circ} a$, specifically in the eyes of their opponents. ${ }^{83}$ Such a distinction certainly splits the Sufis from the Bātini, hence the Sufi like al-Sulami might still be considered "Sunnite". Even though al-Sulami did not touch upon this contentious issue in the introductory section of the Haqā'iq al-Tafsir, al-Wähidi must have been quite certain that Sulami did not believe the Sufi sayings to be the only meaning of the Qur'anic verses.

To know deeper on who is Al-Wāhidi we can clearly say that he belonged to a group of high-ranking intellectuals in Nishapur, as this closeness to the Shafi'ite faction had already appeared in his very carefully selected sentence in his critique. Abū al-Ḥasan 'Ali b. Aḥmad b. Muhammad b. 'Ali al-Wāhidi alNaysaburi was born in Nishapur and died there in 468/1076. His family was among the great merchants of Nishapur. His grandfather, Abū al-Hasan 'Alī al-

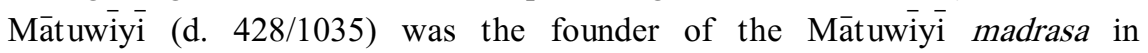

${ }^{81}$ The term Bạtiniyya is defined by Hodgson to be the Ismā ‘ $\bar{i}$ is in medieval times referring to their stress to the batin, the inward meaning behind the literal wording of the sacred texts. In a less specific, the term is also applied to anyone rejecting the literal meaning in favor of its battin. It was in the last sense that certain Muslim philosopher and Sufis were being accused of the battinis, even though some might have defended themselves from the charge of being a bạtini on the ground that they remain acknowledge the zāhir alongside the bătin. (See M. Hodgson 1960, "Bạtiniyya, in EF', I, 1098b-1100a).

${ }^{82}$ See Al-Ghazāì̄, Faụāịh al-Bātiniyya, ed. 'Abd al-Raḥmān Badawì (Cairo: alDār al-Qawmiyya, 1964), 11-17.

${ }^{83}$ See the Hanafi $\bar{i}$ theological stance elaborated by Sa'd al-Din al-Taftāzāni

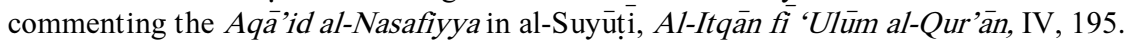


Nishapur. ${ }^{84}$ His father was a successful merchant who always provided strong support to his son to pursue his advanced studies. As a result, al-Wāhidi became an intellectual who had been learning from various great teachers of his age. ${ }^{85}$ In Qur'ānic exegesis, Wāhidī was linked with the renowned Abū Ishāq al-Tha'ālibī (d. 427/1034). ${ }^{86}$

As a result of various scholarly achievements, al-Wāhidi was famous for his works, not only about Qur'ānic exegesis and the occasions of Qur'ānic revelation (asbāb al-nuz $\bar{u})$, but he also had become a renowned Arabic philologist and rhetorician. He composed several tafsirs: al-Basit, al-Wasit, and al-Wajiz. ${ }^{87}$ Looking into al-Wähidi's scholarly character by observing his alTafsìir al-Wajiz, we may conclude that he was typically traditional in his method of interpretation. ${ }^{88}$ Thus, it was on the ground that he was a traditional exegete that the statement was addressed to al-Sulami as his senior mentor of the Shäfi ‘ite fellow in the same native city of Nishapur.

After the demise of al-Wähidi as of the confreres of the Shäfi $\bar{i}$ School of Islamic Law, there would have been much criticism of the Haqā'iq al-Tafsir by al-Sulami, which is unanimously expressed by almost all legal schools within the Sunni community. Despite the fact that al-Wāhidi's critique was barely known as he himself did not mention it in his own work, but it only read through circulated opinion among the $7^{\text {th }} / 13^{\text {th }}$ century traditionists. Among the medieval Shāfi‘ites, Ibn al-Ṣalāh $(\mathrm{d} .643 / 1245)^{89}$ quite comprehensively

${ }^{84}$ Bulliet, The Patricians of Nishapur, 254.

${ }^{85}$ He took Arabic from Abū al-Ḥasan 'Ali b. Muhammad b. Ibrāhīm alQuhunduzí, linguistics from Abū al-Faḍl Aḥmad b Muhammad b Yūsuf al-'Arūdi, and Hadith from several traditionist: Abū Tạhir al-Zayyādi, Abū Bakr Ahmad b. al-Hasan alḤirì, and Abū Ibrāhīm 'Ismāāil b. Ibrāhìm al-Wā'iž, Abd al-Rahmān b. Hamdān alNasrūni, and Ahmad b. Ibrāhīm al-Najjār (al-Subkī (1964), V, 240-241.

${ }^{86}$ Ahmad b Muhammad b Ibrāhìm Abū Isḥāq al-Tha'ālibi was a commentator to the Qur'an, besides he was also known to be the author of prophetic chronicles and a master in the science of the Qur'ān, Arabic and prophetic traditions, see al-Suyut $\bar{i}$, Tabaqāt al-Mufassirīin, I, 28.

${ }^{87}$ Al-Wāhidī, Kitāb al-Wajiz fì Tafsìr al-Qur'ân al-'Aziz, in the margin of alNawāwī al-Jāwì's Marạh Labīd (Surabaya: Dār Ihyā' al-Kutub al-'Arabiyya Andūnisiyya, ca. 2006), 2 vols.

${ }_{88}$ As it is clear by the title al-Wajiz, al-Wähidi provided meanings of the Qur'ānic verses in a brief explanation, based only on a single authority of Ibn 'Abbās that he aimed at giving simple commentary for the sake of the common people who are interested in the science of the Qur'ān, including its commentary. (al-Wāhidi, Kitāb alWajiz, I, 2)

${ }^{89}$ Abū 'Amr Taqī al-Dīn Uthmān b. 'Abd al-Raḥmān, b. Mūsā b. Abī Nașr alShahrazūrì al-Shāfi' 'i was born in 577/1182 in Sharkhān, Iraq. He was a famous trained scholar in the field of Hadith and Fiqh. He began to learn fiqh from his father, who later took him to Mosul in order to learn more on the fiqh of the madhhab al-Shäfi' $\bar{i}$. He 
discussed the statute of Haqā'iq al-Tafsir by al-Sulami in his Fatāwa. ${ }^{-90}$ When asked about his legal opinion on the mystical interpretation to the Qur'ān, Ibn al-Ṣalā began his answer with a quotation of al-Wāhidi's statement, even though Ibn al-Ṣalāh himself seemed to have been doubtful that such a reliable figure like Abū 'Abd al-Raḥmān al-Sulamī had been accused of committing heresy by his junior colleague. In fact, the fatwā was issued for answering a query from an anonymous questioner who was not satisfied with an answer from an anonimous Mufti he had consulted before. The unnamed Mufti who had been asked before was described as seemingly giving a compliment to the mystical commentary. He said that the mystical interpretation like that of alJunayd cannot be included under the framework of tafsir; but under that of "meanings" (ma'ān) that the Sufis are able to gain through the activity of recitation (tiläwa). Such an answer might not have satisfied the questioner as he then finally addressing similar question to Ibn al-Ṣalāh to seek a second legal opinion as a final answer that he would not have to oppose anymore.

What we might derive from the fatwā that classifies the mystical interpretation to be out of the framework of tafsir would rather be a clear apology that the revered Sufi figure like al-Sulami would not have included his collection of mystically inspired utterances gained by the previous Sufis as the solely intended meanings for certain Qur'ānic verses. Such might have probably been allegoric and symbolic "meaning", which were spiritually found by the Sufis during their recitation to the Qur'ān, or from their activities of attentive hearing (samaā'). Ibn al-Ṣalāh's acknowledged that such mystical interpretations, to some extent at least, might come to a true sense (madlü) for the specialists, but such deep understanding might also lead to confusion among the laymen. Moreover, such interpretations might also be included into a genre of Qur'anic eisegesis that was vehemently condemned like that of the Battiniyya, as this would be the case if one believed such allegorical interpretations to be the solely intended meanings of the Qur'anic verses. In short, this apology implied in Ibn al-Ṣalāh's legal opinion about the mystical interpretation conducted by the Sufis represents a definitely moderate opinion,

traveled to Khurasān to master the science of Hadith, then, moved to Syria, staying at Jerusalem giving lectures at the Salāhiyya School, which was established by Salah al-Din al-Ayyübi. He, then, moved to Damascus and dedicated most of his teachings to the Rawāhiyya School. He was appointed to teach Hadith, when the Dār al-Hadith was established in Damascus by al-Malik al-Ashrāf b. al-Malik al-"Ādil b. Ayyūb. He died on $25^{\text {th }} \mathrm{Rabi}^{\overline{6}}$ al-akhīr 643/1245 in Damascus. (J. Robson 1971, "Ïbn al-Ṣalāh," in $E F^{2}$, III, 927a).

${ }^{90}$ See Ibn al-Ṣalāh, Fatāwā Ibn al-Ṣalạh fi al-Tafsì̄ wa al-Hadìth wa al-Uṣūl wa al- 'Aqā'id (Cairo: Idāirat al-Ṭibā'a al-Muniriyya, 1929), 19. 
compared to the other critics among middle age generations of the Shâfi ${ }^{\circ} \bar{i}$ scholars, as we will mention them below.

However, before delving into the criticism from later generations of Shäfi ${ }^{\prime} \bar{i}$ scholars, it is worth considering to see the hardest reaction from other parts, even though they may have been addressed their accusation only to the Bătiniyya among the Shi'ites. In this group was the Hanāifi theologians Abu alHafṣ 'Umar b Muhammad al-Nasafi (d. 537/1142) as he criticized esoteric interpretation in general to be a sort of conversion of obvious meanings of Qur'anic verses, leading to an accusation of heresy of the type committed by the "people of the esoteric (ahl al-bätin). ${ }^{91}$ This seemingly harsh theological argument received a more elaborated explanation in a milder tone in the work of Sa'd al-Dín al-Taftazāni (d. 722/1390) who said that the primary target of such an accusation of heresy was directed only to the framework of ta'wil promulgated by the Bătiniyya among the Shi'ites because they did not accept literal (zāhir) interpretations. ${ }^{92}$ By this late clarification, the Hanafi theologians refrained from rejecting a mystical claim concerning esoteric meanings or spiritual significances within the interpretation to the Qur'anic verses as long as those meanings do not deviate from the desired objective expressed within its outward sense (zähir). However, this milder view would certainly not obliterate the general Hanafite rejection of the so called "inspirational interpretation" as the basis of their opposition to the Bạtini $\bar{i}$ ta'wil. According to them, this kind of esoteric interpretation was based on their wrong theological stance as well as against their rationally epistemic framework. The fact that the mystical commentary was rejected was basically because it stemmed from kashf (unveiling) or mukāshäfa (disclosure), ${ }^{93}$ or ilhām (inspiration) in a more general term. Both, accordingly, could not be classified as valid sources of knowledge (asbāb al-'ilm). Giving a commentary on the Aqa'id by al-Nasafi, al-Taftazāni argued, "The inspiration explained by way of throwing a meaning into [one's] heart through the method of illuminative reception (fayḍ) is not one of the roots of knowledge on the validity of something according to the people of the Truth, until there is a counter argument against the restriction of the roots into

${ }^{91}$ Al-Suyūtịi, Al-Itqān fì 'Ulüm al-Qur'ān, IV, 195.

${ }^{92}$ See al-Suyūtị, Al-Itqān fì 'Ulūm al-Qur'ān, IV, 195.

${ }^{93}$ The term means "lifting and tearing the veil", which usually unidentified as the veil that comes between man and the extra phenomenal world. According to al-Jurjāni in his Ta'rifat, kashf technically means, "to make appear in a complete and actual realization the mysterious senses and the realities which are behind the veil." Experience of kashf could be resulted in the state of mukäshafa meaning "unveiling in the sense of "illumination" or epiphany, which is opposed to the term satr, and istitär (closure). See L. Gardet, "Kashf", $E F^{2}, \mathrm{IV}, 696 \mathrm{~b}$. 
three", ${ }^{94}$ as Abu al-Hafs al-Nasafi principally asserted that the roots of human knowledge are three: the senses, trustworthy reports, and reason. ${ }^{95}$

Among other Sunnite factions, the Hanbalite Ibn Taymiyya was the most outspoken critic of the Haqā'iq al-Tafsir. Representing a traditionist position he asserted, "Abū 'Abd al-Raḥmān al-Sulamī mentioned in his Haqā'iq al-Tafsīir on the authority of $\mathrm{Ja}^{\text {' }}$ far $\mathrm{b}$. Muhammad and the likes several accounts of which experts know that he certainly lied about Ja'far b Muhammad."96 In a general evaluation, Ibn Taymiyya concluded the Haqā'iq al-Tafsìr by al-Sulami to have comprised three sorts of traditions: first, weak traditions (nuqūl ḍa 'ifa) like the ones he had conveyed from Ja'far; second, valid quotations, but wrongly mentioned by the transmitters; third, valid quotations from good quality of authoritative sources. ${ }^{97}$ Some accounts found in al-Sulami's Haqā'iq al-Tafsir would have been classified by Ibn Taymiyya under the category of "wrong hermeneutical procedures" in the form of a "mistaken method of argumentation, but without invalidating the meanings" (al-khata' fi al-dalìl, la fí al-madlüs). Such methodological faults had been also conducted by other groups of scholars among jurists, theologians, and preachers (wä $i z)$, besides the Sufis. ${ }^{98}$ Within his own principles of Qur'ānic interpretation Ibn Taymiyya explained further that what had been conducted by the Sufis was to be classified under the category of "significances" (ishärät). As long as this significance comes from a

94 “Wa al-ilhām al-mufassar bi ilqā'i ma 'nan fī al-qalb bi tarì al-fayḍ laysa min asbāb al-ma 'rifa bi sihhati al-shay' 'inda ahli al-haqq hattà yarida bihi al-i 'tiràd 'alà hastri al-asbāb fī al-thalāthati al-madhkūra." Al-Taftazāni, Sharh al- 'Aqā'id al-Nasafiyya [li Najm al-Dīn 'Umar al-Nasafī] fì Usūul al-Dìn wa 'Ilm al-Kaläm, ed. Claude Salāma (Damascus: Manshūrāt Wizārat al-Thaqāfa wa al-Irshād al-Qawmi, 1974), 41.

95 See A.J. Wensinck, The Muslim Creed: Its Genesis and Historical Development (New Delhi: Oriental Books, 1979), 264.

${ }^{96}$ He wrote, "Qad dhakara Abū 'Abd al-Rahmān fì Haqà'iq al-Tafsìir 'an Ja 'far b. Muhammad wa amthālihi min al-aqwāl al-ma'thüra mā ya 'lamu ahlu al-marifati annahū kadhaba 'alā Ja'far b. Muhammad." Ibn Taymiyya, Majmū Fatāwā, Riyaḍ: Wizārat alShu'ūn al-Islāmiyya wa al-Awqāf wa al-Da'wā wa al-Irshād, 1995, XI, 581.

97 Wa kitāb haqà'iq al-tafsìr li Abì 'Abd al-Raḥmān al-Sulamí yatadammanu thaläthata anwā'in: ạhaduhā nuqūlun ḍā'ífa 'ammān nuqilat 'anhu mithlu akthari mā naqalahu 'an Ja'far... al-thānì an yaküna al-manqülun șahịhan lākinna al-nāqila akhta'a

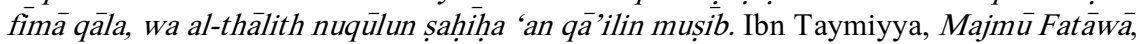
XIII, 242-243.

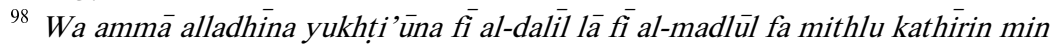
al-süfiyyati wa al-wu 'ā̌ wa al-fuqahà' wa ghayrihim yufassirūna al-qur'āna bima'ānin sahịhatin lākinna al-qur'ān là yadullu 'alayhā mithla kathìrin mimmā dhakarahu Abū 'Abd al-Raḥmān al-Sulamì fì haqà'iq al-tafsìr. Ibn Taymiyya, Majmū Fatāwā, XIII, $362-$ 363. 
valid analogy, it would be accepted. ${ }^{99}$ Within Sufism, such ishärät are to have been applied outside their legal contexts. Sufis usually employ such evidences as some kinds of supporting argument aimed at "arousing desires and inspiring awe" (al-targhib wa al-tarhib) as well as for exhortation of excellent activities (fậa'il al-a'māl). ${ }^{100}$ Such an application is actually highly acceptable as long as it is not in opposition to a formal interpretation of the Qur'an and the Sunna.

In various opinions issued after the diffusion of the Haqā'iq al-Tafsir and other mystical commentaries on the Qur'ān, we observe the tendency to marginalize the mystical interpretation. Such was clear from the Hanafi criticism that the theological consequences of refracting certain Qur'ānic verses from their obvious meaning could lead to an accusation of heresy, due to the Hanafites rejection to include the inspirational meaning to be sorts of valid argument. In Ibn Taymiyya's valuation of al-Sulami's Haqa'iq al-Tafsir, the credentials of the mystical interpretation of the Qur'an could only reach the degree of a wrong hermeneutical procedure. After all, only the Shäfi'ites seemed to hold a moderate appreciation of the symbolic interpretation conducted by the Sufis, though it is still also marginal, categorizing the mystical interpretation to be out of the framework of tafsir. Had it been admitted to the framework of tafsir, such an appraisal would certainly have been rejected by some late hard-liner Shäfi'ite traditionists like al-Dhahabī (d. 748/1348) and Jalāl al-Dìn al-Suyūtî̀ (d. 911/1505), who both were in fact the pupils as well as inheritors of the teachings of Ibn Taymiyya. The approach of later traditionists led to a growing antipathy against Sufism. Such a tendency was very visible in al-Dhahabì's opinion about the Haqā'iq al-Tafsir as recorded in Tabaqāt al-Shāfi 'iyya Kubrā by Tāj al-Dīn al-Subkī (d. 769/1368) saying, "A book named Haqā'iq al-Tafsir belongs him (i.e. al-Sulami); I wish that he had never composed it, because it is perversion and Qarmati [influence] in it; so, beware of the book, [because] you will [certainly] see how odd it is." ${ }^{101}$ This anti-Sufi tendency had also been inherited by al-Suyūti $\bar{i}$ who classified al-Sulami under the category of a heretic. The reason for such a classification, according

${ }^{99}$ Fa inna al-Shaykh $A b \bar{a}$ 'Abd al-Rahmān dhakara fì haqà'iq al-tafsì min alishārāt...fa in kānat al-ishāratu i 'tibāriyyatan min jinsi al-qiyās al-ṣahịh kānat hasanatan maquūlatan. Ibn Taymiyya, Majmū Fatāwā, VI, 376-377.

${ }^{100}$ Fatilka al-ishārāt hiya min bāb al-i 'tibār wa al-qiyās, wa ilhāqu mā laysa bi manșụsin bi al-manșūṣ mithlu al-i 'tibār wa al-qiyās alladhì yasta 'miluhu al-fuqahā' fì al-

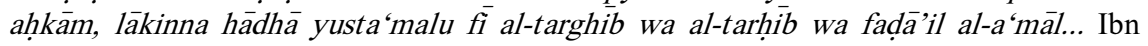
Taymiyya, Majmū Fatāwā, VI, 377.

${ }_{101}$ Al-Dhahabī said, "wa lahu kitāo sammāhu "Haqà'iq al-Tafsìr" laytahu lam yuạannifhu fa innahu tahrî́ wa qarmata fa dūnaka al-kitäb fa satarā al- 'ajab.” Al-Subkī, Tabaqāt al-Shāfi 'iyya al-Kubrā, IV, 147. 
to al-Suyūți, was because his tafsir was as if condemned (ghayru maḥmūd). ${ }^{102}$ It is clear from al-Dhahabi' sources, al-Sulami had to be classified as an unreliable commentator. In addition, a rebellious nature was also attributed to al-Sulami by connecting him with the Qarmatiyya movement, which is something exaggerated like in the case of al-Hallāj. ${ }^{103}$

Despite such harsher criticism, however, al-Sulami continued to receive respect for his capability as a traditional scholar among the early medieval Shāfi'ites. This appraisal is quite clear in al-Subki, who followed al-Khatīib alBaghdādi, defending al-Sulami's reliability in the field of hadith. Al-Khatị asserted that the rank ( $q a d r$ ) of Abu 'Abd al-Rahmān al-Sulami among his native contemporaries was honorable (jalit) as he was also a praiseworthy (mahmūd) traditionist. ${ }^{104}$ Al-Subki followed al-Khațib's opinion as he argued that $\mathrm{Abu}$ 'Abd al-Rahmān was right to have been reliable so far. ${ }^{105}$ At the end of his biographic account of al-Sulami, al-Subki concluded by saying that anyone who had been given an honorable rank should not necessarily be accused of being a Qarmatị. Much criticism directed against the Haqā'iq al-tafsir was because al-Sulami had confined himself in his compilation to mention only some sorts of allegoric interpretation ( ta $^{\prime} w \bar{i} \bar{l} \bar{t}$ ), while it was inconceivable for the Sufis that their words were in contradiction to the formal interpretation. ${ }^{106}$

\section{Concluding Remarks}

What outweighed crucial role of al-Sulamī in composing the Haqa'iq alTafsir was that the political instability and the demeaning cultural atmosphere of Nishapur at the turn of the $5^{\text {th }} / 11^{\text {th }}$ century. This demeaning condition led to schismatic rivalries that cause people to ignore what Ibn Habīb al-Naysaburi called "the distinction between the concept of tafsir and ta 'wir" as it had been propagated almost a half century earlier by al-Māturidi. He had conceived tafsìr

${ }^{102}$ He wrote, "wa innamā awradtuhu fì hādha al-qismi lianna tafsìirahu ghayru mahmüd."Al-Suyūṭi, Tabaqāt al-Mufassirin, I, 98.

${ }^{103}$ The accusation of al-Sulama's being a Qarmați as appears in al-Dhahabi (alSubkī, Tabaqāt al-Shāfi 'iyya al-Kubrāa, IV, 147) was of the reason he was associated with al-Ḥallāj (cf. L. Gardet, "al-Ḥallādj" in $E F^{2}$, III, 99b). In fact, al-Sulami quoted many traditions originated from al-Hallāj in his Haqà'iq al-Tafsir as specifically collected by Massignon, Essai sur les origines du lexique technique de la mystique musulmane, 359 - 412 .

${ }^{104}$ Al-Khatịib al-Baghdādī, Tārikh Baghdād aw Madīnat al-Salām, vol. ii, 348; alSubkī, Tabaqāt al-Shāfí 'iyya al-Kubrā, IV, 145.

${ }^{105}$ Al-Subkì, Tabaqàt al-Shāfí 'iyya al-Kubrā, IV, 145.

${ }^{106}$ Al- Subkì, Tabaqāt al-Shāfi 'iyya al-Kubrā, IV, 147. 
to be somewhat a sort of objective interpretation to the Qur'ān in comparison to the subjective nature of analytical interpretation resulted from the exegetical method of ta'wìl. It was the contentious nature of the Haqa'iq al-Tafsir that the labeling such a collection of mystical tradition was unwillingly applied by later traditionists to name an exegetical work comprises a collection of mystical traditions. This further leads to a confusing context that might have also been resulted from the borderline category by the use of the term tafsir employed by al-Sulami as a Sufi in his traditional way of interpretation on such mystical understanding.

Al-Sulami concerned for exclusively collecting mystical sayings as his source of interpretation. Hence, if we use the framework of Ja'far's division of the fourfold hierarchic layers of meanings: 'ibāra, ishāra, lațā'if, and haqā'iq, alSulami had certainly collected some sorts of extreme categorical interpretations: He employs the method of ibara, which is basic, to provide haqa'iq that was positioned to be the subtlest level of significance and known to be privileged only for the highest rank of prophecy (nubuwwa). It was such an extremity that might have incited controversy and objection to al-Sulamis' tafsir in the following generations.

After all, the controversial nature of the Haqa'iq al-Tafsir may also have been aroused from the extant criticism that the compendium was claimed to have comprised Shi'ite flavor that resembles the character of a Bātini $\bar{i}$ ta'wìi. After conducting a scrutinized observation to the compendium, we can visibly say that al-Sulami play his role as an exeget, not merely a compiler of the mystical compendium. He had applied censorship to some obsolete views in order to suit the Sunnite traditional principles. In this case, the most obvious thing he had censored is the omission of detailed explanation on the Shi'ite doctrine of Muhammadan light, which becomes the basis of emanatif process of cosmogony as it appears in some accounts originated in either Ja'far al-Șādiq or Sahl al-Tustari. Despite still collecting sayings of those two respected figures among Sufis on some of their ethical prescriptions, al-Sulami seemed to consider the doctrine of emanative process of cosmogony to have been obsolete. Besides, it might have been old and derivative of pre-Islamic sources in comparison to the widely spread mainstream Qur'anic doctrine of instantaneous creation out of nothing. He referred to the Baghdadi Sufi tradition of Ibn 'Ațā' in interpretating QS 2:284, "To God belongs all that is in heavens and what is on earth." Commenting the verse, Ibn 'Ațā' said, "To God belong two cosmic realms (kawnāni), of which He is the Innovator (al-mubdi') out of nothing (min ghayri shay'); whoever is occupied with them, is occupied with nothing out of 
everything. ${ }^{107}$ In this clearly traditional stance, al-Sulami was quite consistent as he brought in Ibn 'Atạa's traditional view related to the meaning of Divine Attribute of al-Badí, which is accordingly meant to be the Innovator (mubdi') of things out of nothingness (min ghayri shay'). ${ }^{108}$

In short, despite the contentious nature of its style of interpretation the Haqā'iq al-Tafsìr by al-Sulami was relatively free from any kinds of either Shi'ite elements nor mystical and philosophical notions contradictory to the spirit of the Qur'an like that of the mystical doctrine of Muhammadan light. What certainly conveyed by al-Sulami was a scripturally based Sufism that he certainly plays significant role in the formation of Sunnism. Besides, what had been conceived to be "spiritual significances" of the Qur'anic verses was not aimed at determining the sole intention of the objective meanings of the Qur'ān, but to disclose a complementarily spiritual demand outside its legal context. Sufis usually employ such interpretation for "arousing desires and inspiring awe" (al-targhib wa al-tarhib) as well as for exhortation of excellent activities (faḍ'a'il al-a'māl), upon which the use of weak traditions might not be considered problematic at all. Wallāhu a'lam.

\section{Bibliography}

Abū Zayd. Nașr Hāmid. Mafhūm al-Nașṣ: Dirāsa fī 'Ulūm al-Qur'ān. Cairo: AlHay'a al-Mișriyya al-‘'̄Amma li al-Kitāb, 1993.

-------. Hākadhā Takallama Ibn 'Arabì. Cairo: al-Hay’a al-Mișriyya al-‘'̄Amma li al-Kitāb, 2002.

Al-Baghdādī, Khațīb. Tărīkh Baghdād aw Madīnat al-Salām. Beyrut: Dār alKitāb al-'Arabī, 1970. 14 vols.

Böwering, G. “The Qur'ān Commentary of al-Sulami, in W.B. Hallaq and D.P. Little (Eds.), Islamic Studies Presented to Charles Adams, Leiden: E.J. Brill, 1991, $41-56$.

Bulliet, R. The Patricians of Nishapur: A Study in Medieval Islamic Social History. Cambridge, MA: Harvard University Press, 1972.

Dhahabī, S. Siyar A 'lām al-Nubalā'. Ed. Shu'ayb al-Arna'ūt. Beirut: Mu'assasa al-Risāla, 1993. $9^{\text {th }}$ edition, 25 vols.

${ }^{107} \mathrm{He}$ said, "Qāla Ibn 'Ațā': lillāhi al-kawnāni huwa mubdi'uhuma min ghayri shay'(in); faman ishtaghala bihimā ishtaghala bi lā shay(in) 'an kulli shay'(in).” AlSulami, Haqà'iq al-Tafsir, I, 84.

${ }^{108}$ Al-Sulamí, Haqā'iq al-Tafsìr, IIi, 322. 
-------. Mizān al-I'tidāl fì Naqd al-Rijāl. Ed. 'Al̄i Muhammad al-Bajawìi. Cairo: Dār Ihyā' al-Kutub al-“Arabiyya, 1963. 4 vols.

Gardet, L. "Hakika." In The Encyclopaedia of Islam. New Edition. Leiden: E.J. Brill, ed. B. Lewis [et.al.], 1971. III, 75a.

. "Kashf." In The Encyclopaedia of Islam. New Edition. Leiden: E.J. Brill, ed. B. Lewis [et.al.], 1978. IV, 696b.

. “Al-Hallādj.” In The Encyclopaedia of Islam. New Edition. Leiden: E.J. Brill, ed. B. Lewis [et.al.], 1971. III, 99b.

Al-Ghazālì. Faụāị̣ al-Bātiniyya. Ed. 'Abd al-Raḥmān Badawī. Cairo: al-Dār al-Qawmiyya, 1964.

Hodgson, Marshall G. "Bāținiyya." In The Encyclopaedia of Islam. New Edition. Leiden: E.J. Brill, ed. B. Lewis [et.al.], 1971. I, 1098b-1100a.

Ibn 'Arabī. Al-Futuhăt al-Makkiyya fi Ma'rifat Asrār al-Malakiyya. Cairo: alHay’a al-Miṣriyya al-'Āmma li al-Kitāb, 1972.14 vols.

Ibn 'Asākir. Tärikh Madīna Dimashq wa Dhikr Faḍlihā wa tasmiyat man

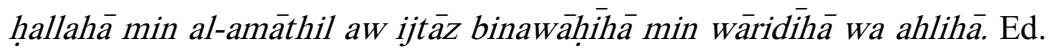
Muhib al-Dīn Abū Sa ‘̄id 'Umar b. Gharāma al-'Amrāwī. Beirut: Dār elFikr, 1995. 80 vols.

Ibn al-Athīr. Al-Kämil fī al-Tärikh. Cairo, 1966. 12 vols.

Ibn al-Ṣalāḥ. Fatāwā Ibn al-Ṣalāh fi al-Tafsìir wa al-Hadìth wa al-Ușūl wa al'Aqā'id. Cairo: Idārat al-Tibā'a al-Muniriyya, 1929.

Ibn Kathīr. Tafsìir al-Qur'ān al-'Azìim. Edited by Sāmī b. Muhammad Salāma. Riyaḍ: Dār Tayyiba, 1999. 8 vols.

Ibn Khallikān. Wafayāt al-A 'yān wa Anbā' Abnā' al-Zamān. Edited by Iḥsān 'Abbās. Beirut: Dār Șādir, 1968. 8 vols.

Ibn Taymiyya. Majmā Fatāwā. Edited by 'Abd al-Raḥmān b. Muhammad b. Qāsim with the assistance of his son Muhammad b. 'Abd al-Raḥmān and introduced by 'Abd Allāh b. 'Abd al-Muhsin al-Turkī. Riyaḍ: Wizārat alShu'ūn al-Islāmiyya wa al-Awqāf wa al-Da“wā wa al-Irshād, 1995. 35 vols.

-------. Minhāj al-Sunna al-Nabawiyya fī Naqụ Kalām al-Shī‘a wa alQadariyya. ed. Muhammad Rashād Sālim. Cairo: Mu’assasa Qurțūba, 1962. 2 vols.

Al-Jurjānī. Al-Ta'rifät. Ed. 'Abd al-Raḥmān 'Ūmayra. Beirut: 'Ālam al-Kutub, 1987.

Al-Kalābadhī. Al-Ta'arruf li Madhhab Ahl al-Tasawwuf. First ed. A.J. Arberry. Cairo: Maktabat al-Khanji, 1933. 
Madelung, W. "Al-Māturidi." In The Encyclopaedia of Islam. New Edition. Leiden: E.J. Brill, 1986. Ed. C.E. Bosworth [et.al.]. VI, 846a.

Makkī, Abū Talib, Qüt al-Qulūb. Cairo: al-Maṭba'a al-Miṣriyya, 1932. 2 vols.

Massignon, L. Essai sur les origines du lexique technique de la mystique musulmane. Paris : J. Vrin, 1954.

--------. Essays on the Origins of the Technical Language of Islamic Mysticism. Transl. Benjamin Clark. Notre Dame: University of Notre Dame Press, 1997.

-------. The Passion of Halläj. Mystic and Martyr of Islam. Transl. from the French with a biographical foreword by Herbert Mason. Princeton: Princeton University Press, 1982. 4 vols. Bollingen Series, 98.

McAuliffe, J.D. Qur'ānic Christians: An Analysis of Classical and Modern Exegesis. Cambridge: Cambridge Univ. Press, 1991.

-------. “Qur'ānic Hermeneutics: The Views of al-Tabari and Ibn Kathīr.” In A. Rippin. Approaches to the History of the Interpretation of the Qur'an. Oxford: Clarendon Press, 1988, 46 - 62.

Al-Qushayrī. Arba' Rasā'il fì al-Tașawwuf. Ed. Qāsim al-Sāmarrā'̄i. Baghdad: al-Majma' al-'Ilmi al-'Irāqī, 1969.

Kitāb Tartīb al-Sulūk fī Tarìq Allāh li al-Imām Abì al-Qāsim 'Abd alKarīm b. Hawāzin al-Qushayri (d. 465). Transl. and ed. by Qāsim al-

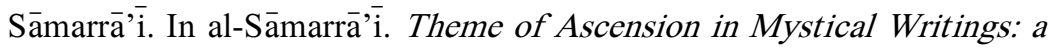
Study of the Theme in Islamic and non-Islamic Writings. Baghdad: National Printing, 1968, 165 - 177.

--------. Al-Risāla al-Qushayrìyya fī 'Ilm al-Tasawwuf. Eds. Ma'rūf Zurayq and

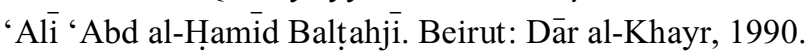

Robson. "Ibn al-Șalāh." In The Encyclopaedia of Islam. New Edition. Leiden: E.J. Brill, 1971. Ed. B. Lewis [et.al.]. III, 927a.

Ṣafadi. Das Biographische Lexikon des Salāhaddīn al-Khalì ibn Aibak alSafadi Kitāb al-Wāfī bi al-Wafayāt. EEd by H. Ritter, Iṇsān 'Abbās, S. Dedering, M.Y. Najm, A. Amara and J. Sublet, Widad al-Qāọi, Aiman Fu'ād Saiyid, B. Jonkisch and M. al-Hujairi. Wiesbaden: Franz Steiner Verlag, 1962-1988; Beirut: in kommission bei Klaus Schwarz Verlag Berlin, 2004.

Al-Sha'rānī. Al-Ṭabaqāt al-Kubrā. Cairo: np, 1897. 2 vols.

Al-Subkī. Tabaqāt al-Shāfi 'iyya al-Kubrā. Ed. Maḥmūd Muhammad al-Ṭanāḥ̄ and 'Abd al-Fattāh Muhammad al-Huluw. Cairo: Isā al-Bābì al-Ḥalabìi, 1964. 10 vols. 
Al-Sulamī. Adāb al-Suḥba wa Husn al-'Ishra. Edited with an introduction by M.J. Kister. Jerusalem: The Israel Oriental Studies, 1954.

-------. Haqā'iq al-Tafsìr: Tafsìir al-Qur'ān al-'Azìz. Ed. Sayyid 'Imrān. Beirut: Dār al-Kutub al-'Ilmiyya, 2001. 2 vols.

-------. Jawāmi $\bar{A} d \bar{a} b$ al-Șüfiyya wa 'Uyūb al-Nafs wa Mudāwamātuhā. Edited with an introduction by E. Kohlberg. The Max Schloessinger Memorial Series no. 1. Jerusalem: Jerusalem Academic Press, 1976.

-------. Kitāb Tabaqāt al-Ṣüfiyya. Ed. J. Pedersen. Leiden: E.J. Brill, 1960.

Al-Suyūî̀. Al-Itqān fī 'Ulūm al-Qur'ān. Ed. Muhammad Abū al-Faḍl Ibrāhīm. Cairo: Maktaba al-Mashhad al-Ḥusayni, 1967. 4 vols.

-------. Tabaqāt al-Mufassirīn. Ed. 'Alì Muhammad 'Umar. Cairo: Maktaba Wahba, 1977.

-------. Lubb al-Albāb fī Tahrì̄ al-Ansāb. Eds. Muhammad Ahmad 'Abd al'Azīz, and Ashraf Aḥmad 'Abd al-'Azīz. Beyrut: Dār al-Kutub al'Ilmiyya, 1991. 2 vols.

Al-Ṭabarāni. Al-Mu'jam al-Awsat. Ed. Mạ̣mal-Ṭaḥhān. Riyadh: Maktaba alMa‘ārif, 1985. 11 vols.

Al-Tabari. Jāmi' al-Bayān 'an Ta'wīl Āy al-Qur'ān. Edited by A.M Shākir. Riyād: Majma‘ Malik Fahd, 2000. 24 vols.

Al-Taftazāni. Sharh al- 'Aqā'id al-Nasafiyya [li Najm al-Dīn 'Umar al-Nasafī] fì Uṣūl al-Dīn wa 'Ilm al-Kalām. Ed. Claude Salāma. Damascus: Manshūrāt Wizārat al-Thaqāfa wa al-Irshād al-Qawmì, 1974.

Al-Tustari, Sahl b. 'Abd Allāh. Tafsìir al-Qur'ān al-Ażim. Cairo: Dār al-Kutub al-'Arabiyya al-Kubrā, 1911.

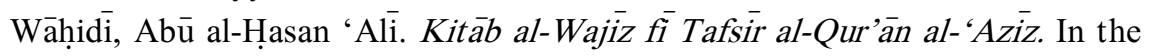

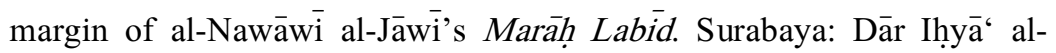
Kutub al-'Arabiyya Andūnisiyya, ca. 2006. 2 vols.

Watt, W.M. The Formative Period of Islamic Thought. Edinburgh: Edinburgh University Press, 1973.

Wensinck, A.J. The Muslim Creed: Its Genesis and Historical Development. New Delhi: Oriental Books, 1979. Reprint Corporation, $2^{\text {nd }}$ ed.

Al-Zarkashī. Al-Burhān fī 'Ulūm al-Qur'ān. Ed. Muhammad Abū al-Faḍl Ibrāhīm. Cairo: Dār Ihỵā’ al-Kutub al-'Arabiyya, 1957. 4 vols. 